Western University

Scholarship@Western

2021

\title{
INDIGENOUS PEOPLES AND RESPONSIBLE INVESTMENT IN CANADA
}

Diane-Laure Arjaliès

Western University, darjalies@ivey.ca

Julie Bernard

Laval University, julie.bernard.5@ulaval.ca

Bhanu Putumbaka

Follow this and additional works at: https://ir.lib.uwo.ca/iveypub

Part of the Business Commons

Citation of this paper:

Arjaliès, D-L., Bernard, J., Putumbaka B., (2021), Indigenous Peoples and Responsible Investment in Canada, Western University, London, Canada, DOI: https://doi.org/10.5206/092021ip26 


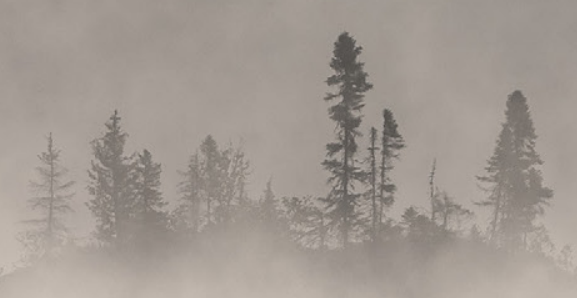

\section{Indigenous Peoples and Responsible Investment in Canada}

Dr. Diane-Laure Arjaliès, Julie Bernard, and Bhanu Putumbaka 


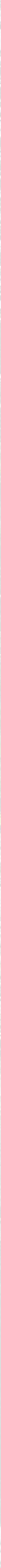




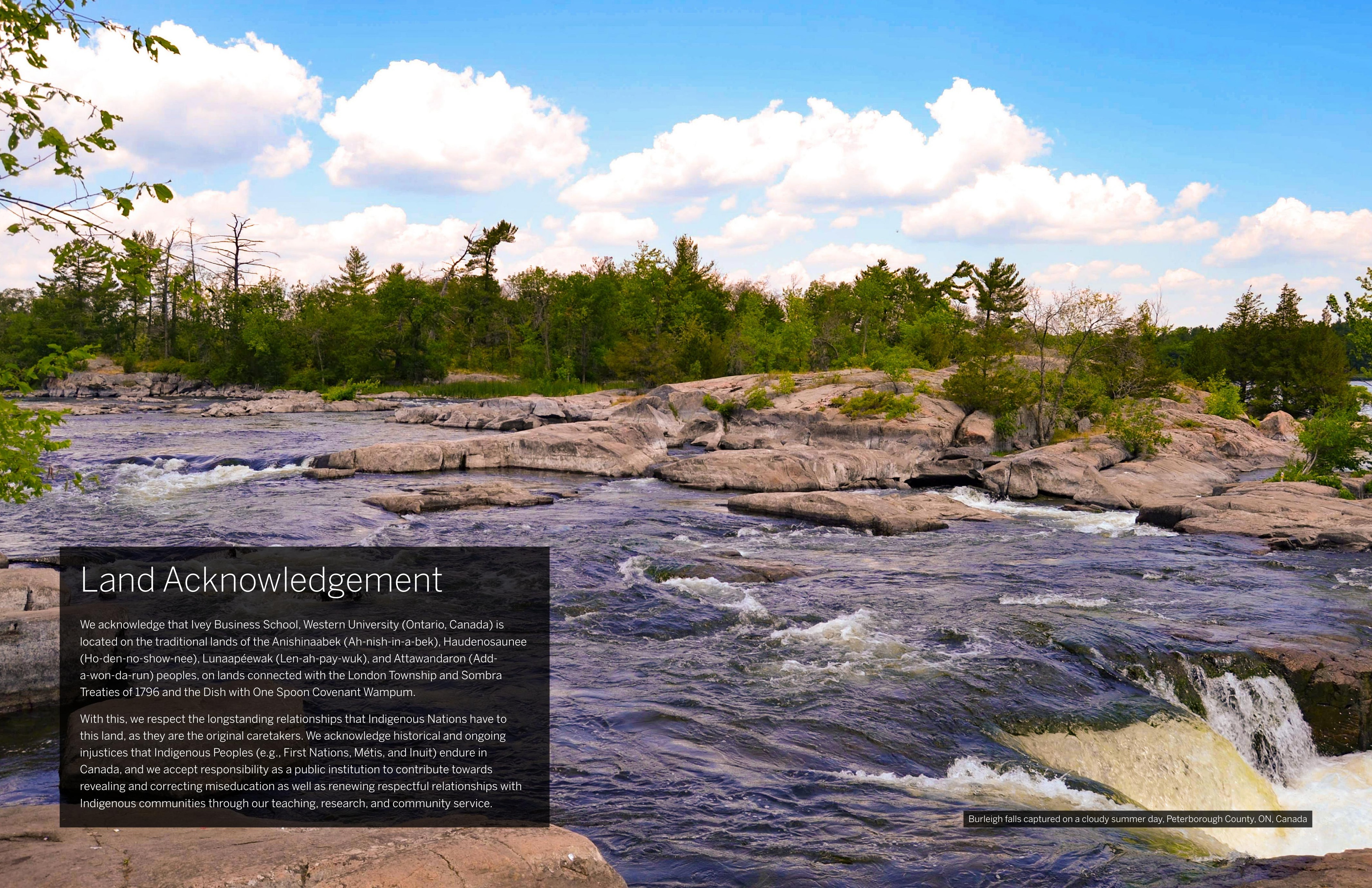




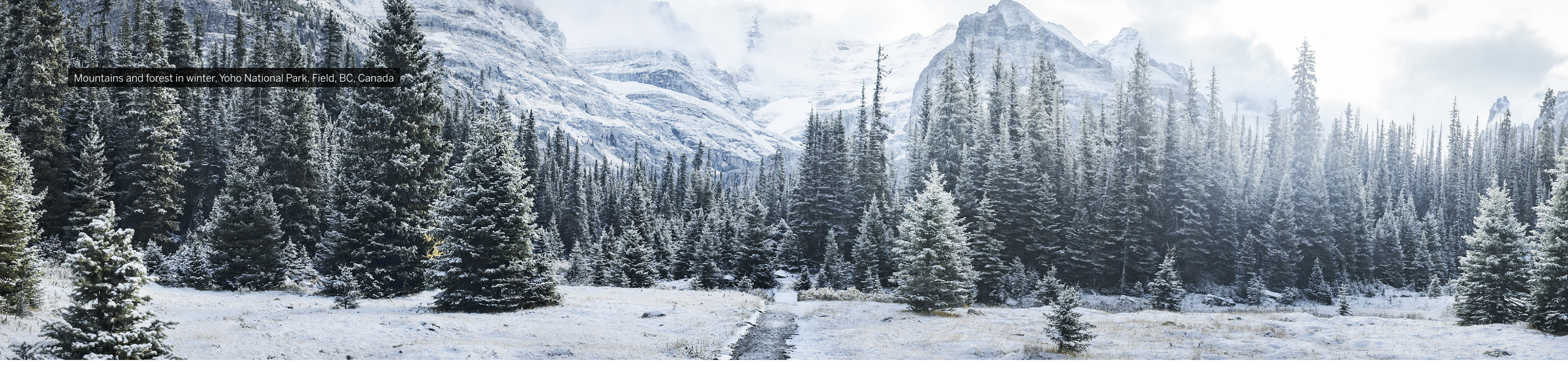

\section{Foreword}

In Canada, the engagement between Indigenous and non-Indigenous Peoples can be viewed through the lens of reconciliation. The Truth and Reconciliation Commission (TRC) was established in 2007 as part of the Indian Residential Schools Settlement Agreement to facilitate reconciliation among former students at residentia schools, families, communities, and Canadians. In June 2015, the TRC submitted its final report, which included 94 Calls to Action or recommendations to all levels of Canadian society to further reconciliation between Indigenous and non-Indigenous Peoples. The Call to Action 92 focuses on business and reconciliation with the United Nations Declaration on the Rights of Indigenous Peoples (UNDRIP) as a reconciliation framework. Based on the recommendations from the TRC, the Government of Canada endorsed the UNDRIP without qualification in 2016 and introduced the legislation to implement the declaration in December 2020

"Reconciliation is about establishing and maintaining a mutually respectful relationship between Aboriginal and non-Aboriginal peoples in this country. In order for that to happen, there has to be awareness of the past, an acknowledgment of the harm that has been inflicted, atonement for the causes, and action to change behaviour."

- Truth and Reconciliation Commission of Canada
This report aims to create a safe space to engage the Canadian responsible investment industry in the process of truth and reconciliation. It outlines the current relationships between Indigenous Peoples and the responsible investment (RI) industry in Canada and offers recommendations to build bridges and make progress towards reconciliation.

The World Bank estimates that there are 370 to 500 million Indigenous Peoples worldwide in more than 90 countries. It is essential to engage with Indigenous Peoples according to the context in which they evolve. Though this report focuses on Canada, the report's findings and recommendations have implications for investors globally. Economic actors must address social inequalities and systemic racism to contribute to an inclusive growth that creates opportunities for all. Including Indigenous Peoples in the allocation, distribution and valuation of capital is an essential step towards this endeavour. In addition, inclusive companies that manage Environmental, Social, and Governance (ESG) risks and improve outcomes for Indigenous Peoples are also better investments

We encourage our readers to bear witness to the voices of Indigenous Peoples who told their stories of loss and the recommended actions for acknowledgment and reconciliation in the Truth and Reconciliation Commission's accounts.

This report's views are ours and should not be ascribed to Indigenous Peoples nor our interviewees.

P. P. Kowali S (2018) The Other Diversity Dividend Harvard Business Review. https//thbrorg/2018/07/the-other-diversitydividend. 


\section{ABOUT THE AUTHORS}

Dr. Diane-Laure Arjaliès is Associate Professor at the Ivey Business School, Western University. An ethnographer, she aims to push the boundaries of knowledge and practice by investigating how the fashioning of devices and collective actions can help transform financial markets towards sustainable development. She is currently designing Indigenous-led conservation finance instruments to channel capital towards protecting ecosystems. A settler of French origin, she moved from Paris to what is now called Canada in 2015.

Julie Bernard is a PhD candidate in management at Université Laval (Wendake-Nionwentsio Land). Her doctoral thesis is on shareholder engagement strategies (mainly proxy voting) in a responsible investment context and on stakeholder engagement in materiality assessment in sustainability reporting. Before her doctoral studies, she worked for several years in responsible investment at Groupe investissement responsable (GIR) Inc. She was involved in this community through the Initiative finance durable-Finance Sustainability Initiative (IFD-FSI, now part of finance Montréal).

Bhanu Putumbaka, MBA'19 is a graduate of Ivey Business School. She started her career in capital markets, working for the investment banking division of one of the largest banking groups in India. Since graduating from Ivey, her curiosity and passion for sustainable finance has led her to become an independent consultant, collaborating on projects with the Ivey Business School, the Multi-Capital Performance Research Centre at Audencia Business School, MaRS Solutions Lab and the United Nations Global Compact (UNGC).

For questions and comments, please contact Dr. Diane-Laure Arjaliès at darjalies@ivey.ca.

To cite this report:

Arjaliès, D-L., Bernard, J., Putumbaka B., (2021), Indigenous Peoples and Responsible Investment in Canada, Western University, London, Canada, DOI: https://doi.org/10.5206/092021ip26

\section{(c) (i) \$}

This work is licensed under a Attribution-NonCommercial - CC BY-NC

This license lets others remix, adapt, and build upon your work non-commercially, and although their new works must also acknowledge you and be non-commercial, they don't have to license their derivative works on the same terms.

This report was funded by the lan O. Innatowycz Institute for Leadership and the Ivey Centre for Building Sustainable Value.

\section{IAN O. IHNATOWYCZ INSTITUTE FOR LEADERSHIP}

Since its inception in 2010, the lan O. Innatowycz Institute for Leadership at the Ivey Business School has been at the centre of leadership thought, inquiry, and education into what makes a better leader through its focus on leader character. Its research is integrated into Ivey's degree and executive education programs so students can assess and increase their own leadership capacities and exercise character-based leadership. Through a wide range of outreach activities to the public, private, and not-for-profit sectors, the Institute seeks to elevate the importance of character alongside competence in the practice of leadership, and thereby enhance individuals' decision-making efficacy and generate sustained excellence for organizations.

The Institute supports the development of global citizens who have strength of character, strive to make a difference, and contribute to the flourishing of teams, organizations, communities, and societies. Examining and addressing the impact of leaders and leadership on issues around equity, diversity, and inclusion squarely falls within the Institute's mandate. As such, its mission includes the cultivation of dimensions of leader character - such as humanity, humility. justice, accountability, integrity, courage, transcendence, and collaboration - that facilitate truth, reconciliation and equality, and the creation of fair, inclusive, and sustainable societies

To be deliberate in planning such a transformation, we need business leaders to tap into accountability, justice, humanity, and transcendence, which are dimensions of the Ivey Leader Character Framework espoused by the lan O. Ihnatowycz Institute for Leadership and the sustainability know-how developed by the Ivey Centre for Building Sustainable Value.

For more information on the Institute's research, teaching, and outreach, visit: ivey.ca/leadership

\section{THE CENTRE FOR BUILDING SUSTAINABLE VALUE}

The Ivey Centre for Building Sustainable Value, one of the first sustainability centres in a business school globally, is recognized for its excellence and track record in research and teaching. We equip business leaders and future leaders - Ivey's students - to succeed in a world where sustainability drives organizational success.

One of the Centre's major priorities is sustainable finance. The incorporation of Environmental, Social, and, Governance (ESG) factors in investment decision-making is now growing rapidly. However, there remains an urgent need for new financial instruments that can help address the complex challenges facing communities and ecosystems. The Centre's Sustainable Finance Priority Area supports the design and deployment of

innovative financial tools and approaches to catalyze the transition to sustainable development. Our research focuses on key priorities for Canada - including ecosystem conservation, green infrastructure, blended finance and investment in the success of Indigenous communities.

ivey.uwo.ca/sustainability 


\section{IVEY BUSINESS SCHOOL, WESTERN UNIVERSITY}

The Ivey Business School recognizes its responsibility to acknowledge and engage in reconciliation by demonstrating actions that align with the Truth and Reconciliation Commission's Calls to Action. In particular we recognize our need to work collectively, as a community, to respond to Call to Action 92, which offers a roadmap for Business Schools and the Business community to think about and practice reconciliation.

As a Business School we recognize that we need to actively engage and commit to designing decolonial practices in relationship with Indigenous colleagues, students and community partners. Our approaches to decolonization need to be shaped by those Indigenous voices who have not been afforded privilege, power or sovereignty through processes of colonization.

As a means of confronting the privilege and power of being settler scholars, we recognize that we need to situate ourselves in the space of becoming constant and intentional learners. That is, within the context of settler scholar research, we recognize that a commitment to reconciliation requires that we re-imagine our research relationships with Indigenous peoples and Indigenous knowledge systems, such that we understand Indigenous knowledge is not ours to discover. Rather, as settler scholars we have a responsibility to learn from Indigenous knowledge.

As a Business School we recognize there is much work to be done, and that the practice of reconciliation requires sustained commitment to not only actions, but also a sustained practice of confronting the places within current financial systems and sectors where Indigenous voices are absent. The following report not only maps out the spaces and places within the Canadian responsible investment industry where Indigenous voices are needed, but also offers a necessary roadmap for how this sector and its partners, may begin to walk a path toward honouring truth and practicing reconciliation.

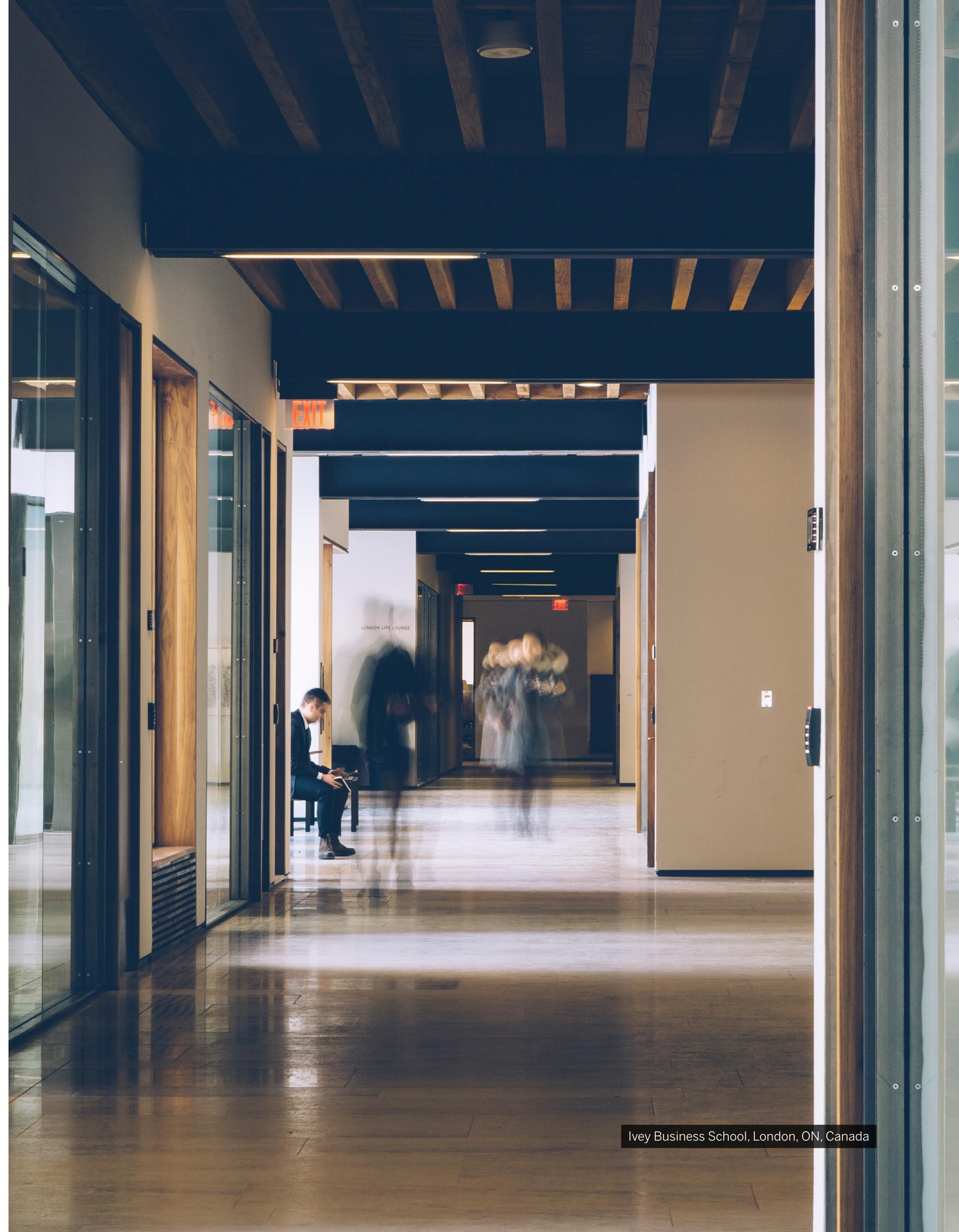




\section{On the Role of Universities and Business Schools in the Process of Truth and Reconciliation}

In the last decade, the Government of Canada has begun to devote resources and efforts to truth-telling and recognizing its misguided efforts to assimilate Indigenous Peoples. In June 2008, the Government of Canada officially established the Truth and Reconciliation Commission of Canada (TRC) as a process of truth-saying. Several reasons motivated its foundation: to listen to the experiences of survivors of the residential school system; to document the damages inflicted by the residential school system; to educate Canadians on the residential school system and the harm it caused on individuals, communities, and cultures: and finally, to suggest ways of moving forward together to build Canada's future. The final report was released in June 2015 (Truth and Reconciliation Commission of Canada, 2015). It shared the contributed stories and experiences and outlined 94 Calls to Action to establish and maintain a mutually respectful relationship between Indigenous and non-Indigenous Peoples for truth and justice in this country. Call to Action 92 invites Canadian businesses to join the truth and reconciliation process. Some examples of this participation include engaging in meaningful consultations with Indigenous Peoples before embarking on economic development projects; ensuring that Indigenous Peoples have equitable access to economic opportunities such as jobs, training, and education; and finally, providing education to staff on the history of Indigenous Peoples as well as skills-based training on intercultural competency, anti-racism, and more. In 2017, Indigenous engagement by corporate Canada scored only 13 out of 100, indicating the need for more actions (Indigenous Works, 2017).
Historically, Canadian universities played a central function in the processes of colonization. Up until the 1960s, Indigenous Peoples had limited access to the universities and still, to this day, are underrepresented and under-resourced in the university system. Further, university research agendas often neglected the knowledge of Indigenous Peoples, misinterpreted their teachings, and 'othered' their culture, positioning it as inferior, illiterate, and uncivilized. To reverse these negative processes, Canadian universities must now engage in decolonization, which aims to change colonialism's negative and disempowering nature in research and education. Researchers must also improve Indigenous Peoples' access and experience within the university system. Engaging Indigenous Peoples in the production of research is vital as it contributes to building relationships and meaningful dialogue between Indigenous and non-Indigenous Peoples.

Three calls issued by the Truth and Reconciliation Commission (TRC) are particularly relevant to business schools: 62 (ii), integrating “Indigenous knowledge and teaching methods into classrooms;" 65, establishing "a national research program with multi-year funding to advance understanding of reconciliation;" and 92 , targeted at the business sector, to adopt and apply the United Nations Declaration on the Rights of Indigenous Peoples (UNDRIP) as a reconciliation framework. Business schools educate business leaders and research business practices: they have an integral role in reconciliation.

This report aims to contribute to this process by engaging in research that aims to be anti-oppressive, culturally sensitive, and community-centred.

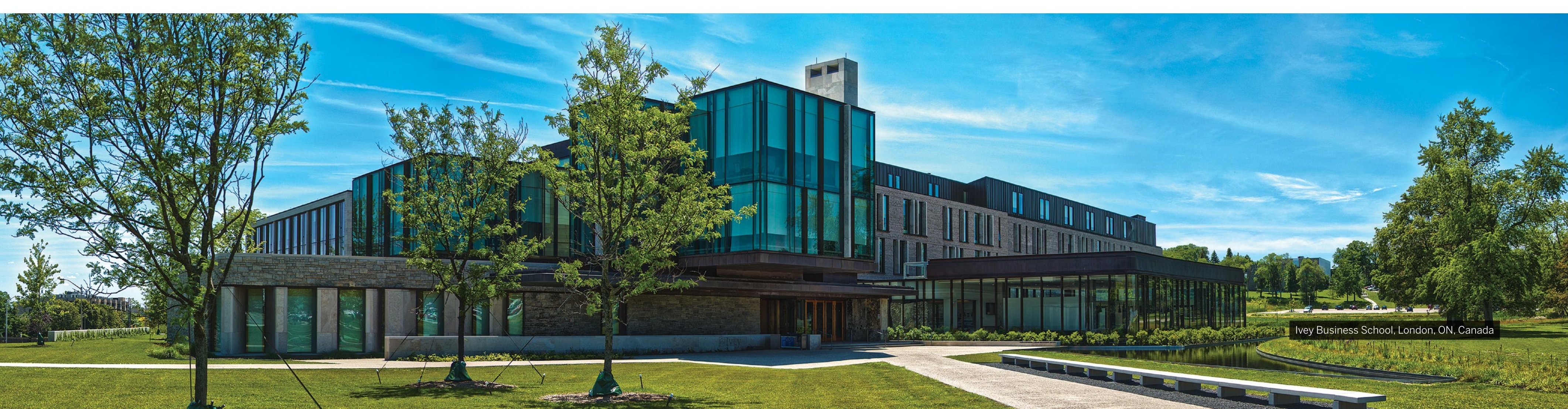




\section{Executive Summary}

This report explores the engagement between Indigenous Peoples and the Responsible Investment (RI) industry in Canada. Based on interviews with stakeholders, observation of industry conferences, and documentary evidence collected during the first year of the pandemic (i.e., March 2020-March 2021), this report offers an overview of the current discussions regarding Indigenous Peoples in the RI industry.

$\mathrm{Rl}$ is an investment approach that incorporates Environmental, Social, and Governance (ESG) factors into the selection and management of investments (RIA, 2021). In 2019, the Responsible Investment Association (RIA) estimated that assets in Canada managed using one or more RI strategies ${ }^{2}$ were worth $\$ 3.2$ trillion, or 61.8 per cent, of total Canadian assets under management (RIA, 2020).

The report envisions the interactions between Indigenous Peoples and RI through six topics:

1. Recognition of Indigenous rights;

2. Diversity and inclusion (of Indigenous Peoples);

3. Building a thriving Indigenous economy through partnership;

4. Fiduciary duty and Indigenous Peoples:

5. Building an inclusive and just transition to a low-carbon economy through partnership; and,

6. Indigenous environmental stewardship

These topics reflect the current threads of discussions that could be observed in the RI industry. The report analyzes how the Canadian RI industry discusses these topics through each step of the investment chain (Arjaliès et al., 2017). The investment chain is a complex system comprising various actors ranging from asset owners, asset managers, investee companies, and service providers performing functions such as strategic asset allocation, asset manager selection, asset allocation, sourcing and due diligence, investment allocation, risk management, performance measurement, reporting, proxy voting, and engagement etc.

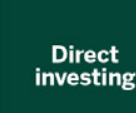

Indigenous
Peoples
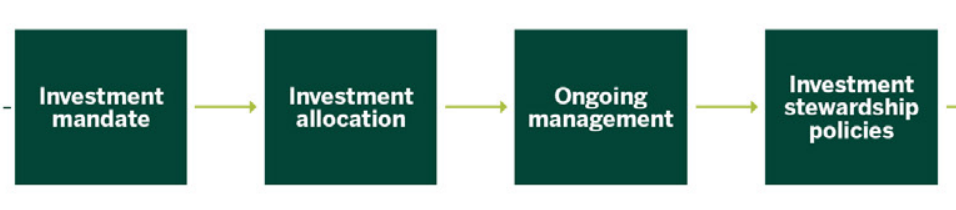

Asset manager activitios

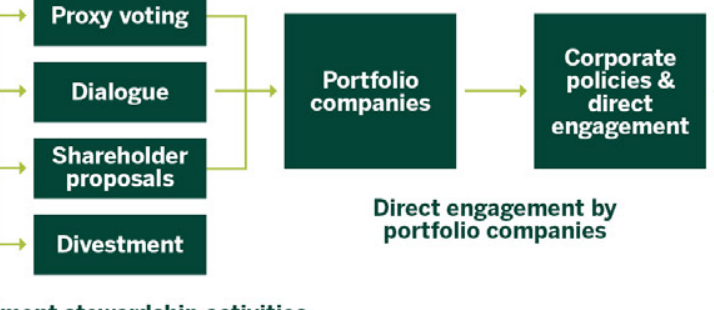

Figure 1: The Investment Chain adapted from Arjaliès et al., 2017 and World Economic Forum, 2014

THE INVESTMENT CHAIN

\begin{tabular}{|l|l|}
\hline TERM & DESCRIPTION \\
\hline Internal policies & Procedures that establish rules of conduct within an organization. \\
\hline Investment Policy Statement & $\begin{array}{l}\text { Describes investment return and risk objectives, asset allocation, risk } \\
\text { management, and governance. }\end{array}$ \\
\hline Strategic asset allocation & $\begin{array}{l}\text { A portfolio strategy whereby the investor sets target allocations for various } \\
\text { asset classes and rebalances the portfolio periodically. }\end{array}$ \\
\hline $\begin{array}{l}\text { Asset manager selection and } \\
\text { oversight }\end{array}$ & $\begin{array}{l}\text { A broad set of qualitative and quantitative considerations to determine } \\
\text { whether a manager displays skill and the likelihood that the manager will } \\
\text { continue to display skill in the future. }\end{array}$ \\
\hline $\begin{array}{l}\text { Investment Management } \\
\text { Agreement }\end{array}$ & $\begin{array}{l}\text { A legal document specifying the appointment, authorities and duties, fees, } \\
\text { expenses, termination, renewal, etc., of the investment manager. }\end{array}$ \\
\hline Research & $\begin{array}{l}\text { Researching themes, asset classes, industries, and companies that fit } \\
\text { investment thesis. }\end{array}$ \\
\hline
\end{tabular}


Asset selection, sourcing, and Sourcing, screening, and due diligence ensure assets meet the investment due diligence

Sourcing, screening, and due diligence ensure
thesis with the appropriate risk/return profile.

Investment mandate

A set of instructions on how a pool of assets should be invested.

\begin{tabular}{l|l} 
Investment allocation $\quad$ Periodic rebalancing of portfolios based on a reassessment of risks and \\
\hline
\end{tabular} returns.

Investment stewardship Guidelines that inform proxy voting, shareholder dialogue, and proposals. policies

\section{Proxy voting}

A proxy vote is a ballot cast by one person or firm for a company's shareholder who cannot attend a meeting or who does not want to vote on an issue. Shareholders vote on various issues, including the election of board members, merger or acquisition approval, or approving a stock compensation plan.

Shareholder dialogue

Investors are engaged in shareholder dialogue when they communicate their concerns, discuss with senior management or the board of directors, and follow up on possible improvements to be made in risk management, governance, and operations of the company.

Shareholder proposal A document formally submitted by a shareholder to a publicly traded company advocating the company take a specific course of action.

Divestment

Investors selling their interest in assets based on the reassessment of risks and returns.

Portfolio companies' direct Employee engagement, Indigenous engagement, procurement, social and

engagement

Employee engagement, Indige

\section{KEY MESSAGES OF THE REPORT}

1. Indigenous Peoples and their economic, social, and environmental well-being are relatively absent from the conversations in the Canadian Responsible Investment (RI) industry. Among the different topics related to the interactions between Indigenous Peoples and responsible investors, only the

recognition of Indigenous rights and the diversity and inclusion (of Indigenous Peoples) surface in the discussions regularly;

2. Indigenous Peoples are rarely involved in formulating RI policies and practices, even when the latter directly impact them. Including Indigenous Peoples in investment decisions should not be perceived as mutually exclusive from adopting Environmental, Social, Governance (ESG) criteria:

3. Issues that relate to Indigenous Peoples are not visible in ESG reporting. The current international ESG reporting standards do not offer guidance on how to include Indigenous perspectives in ESG reporting;

4. Responsible investors usually assess Indigenous rights and concerns through the lens of risk management. While risk management is a critical component for investment decisions, it limits opportunities for the RI industry to contribute to reconciliation or the building of opportunities for all peoples to achieve their full potential and shared prosperity;

5. To contribute to reconciliation, the investment industry should include Indigenous perspectives across the investment chain. Rethinking our (investment) values and the current system of allocation, distribution, and valuation of capital are needed to engage in this endeavour; and,

6. RI can help address systemic challenges such as social inequalities, racism, climate change, and biodiversity loss. Still, this transformation requires building a more diverse decision-making process that includes Indigenous Peoples (among other minorities).

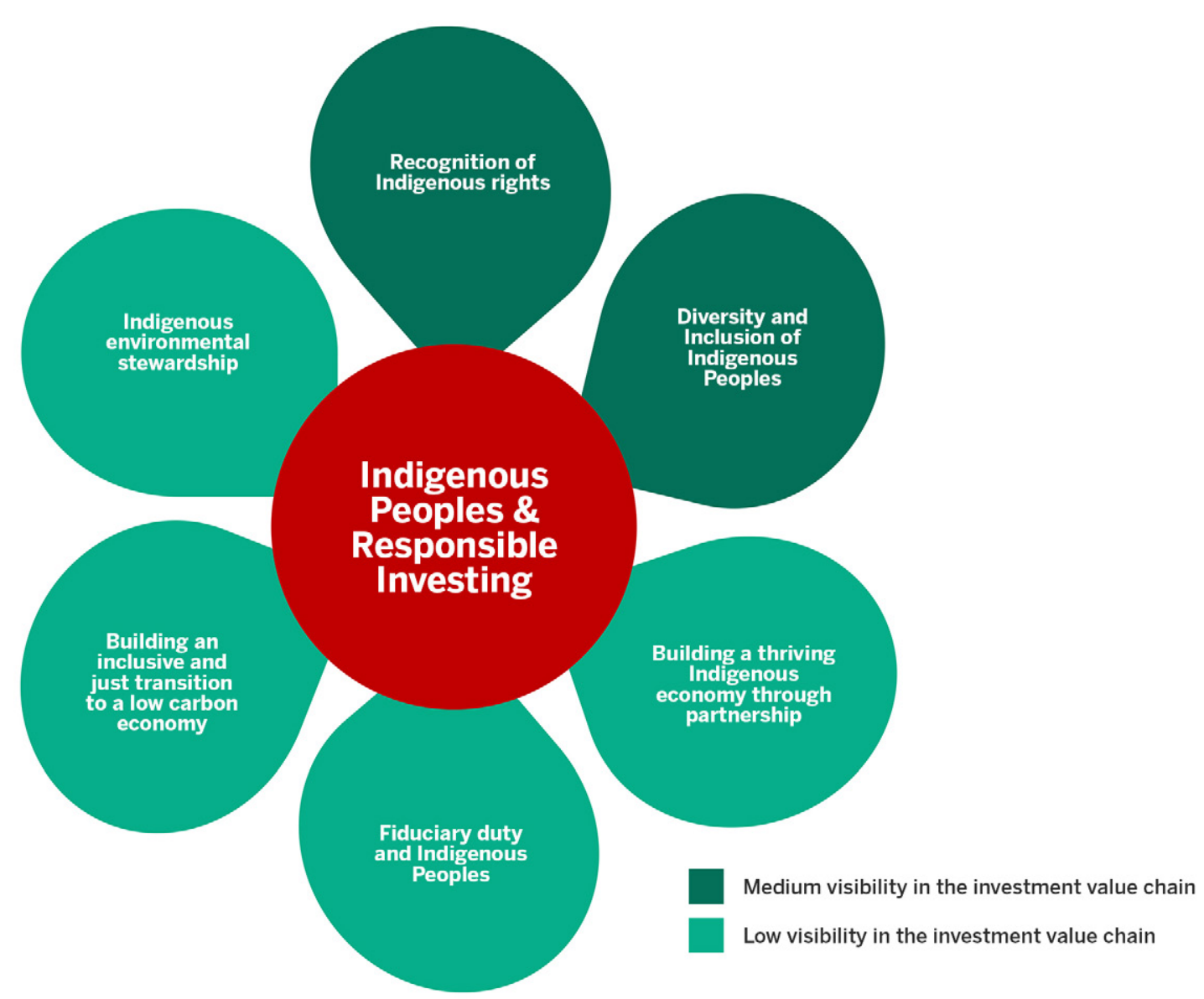

Figure 2: Types of interactions between Indigenous Peoples and the Canadian Responsible Investment (RI) industry 


\section{KEY RECOMMENDATIONS OF THE REPORT}

The Canadian RI industry can take several immediate actions to contribute to Indigenous Peoples' economic, social, and environmental well-being.

Recognition of Indigenous rights

What are the recommended next steps?

Referencing and explicitly recognizing the need to support the United Nations Declaration on the Rights of Indigenous Peoples (UNDRIP)

Communicating expectations on Free and Prior Informed Consent (FPIC)

Assessing actual or potential negative impacts on

Indigenous Peoples' rights

Diversity and inclusion of Indigenous Peoples

What are the recommended next steps?

Where should they be implemented in the investment chain?

Training employees on Indigenous cultural awareness Internal policies of investors and asset managers and sensitivity

Corporate policies of portfolio companies (through investment stewardship policies and activities)

Implementing comprehensive policies on Indigenous Internal policies of investors and asset managers representation among employees and boards of

directors

Corporate policies of portfolio companies (through investment stewardship policies and activities)
Building a thriving Indigenous economy through partnership

What are the recommended next steps?

Where should they be implemented in the investment chain?

Investing in Indigenous-led (impact) investing products

Direct investments by investors

Creating new investable products that benefit Indigenous Peoples

Supporting Indigenous investors in capacity-building and due-diligence processes

Designing procurement policies for Indigenous

Corporate policies of portfolio companies (through

businesses

investment stewardship policies and activities)

Fiduciary duty and Indigenous Peoples

What are the recommended next steps?

Where should they be implemented in the investment chain?

Training and building capacity for Indigenous rights

Internal policies of investment managers

Assessing the impact of company practices on Indigenous Peoples

Monitoring risks and opportunities for Indigenous rights

Educating and engaging Indigenous investors on proxy voting that relates to Indigenous rights
Investment due diligence

Portfolio management

Shareholder engagement policies and activities 
Improving access to capital for Indigenous financial institutions and Indigenous-led initiatives in lowcarbon projects

Direct investments by investors; asset managers have the onus to raise such investment opportunities and prospects with their clients

Building capacity to support Indigenous investors in Direct investments and co-investments by investors their due-diligence process

Encouraging portfolio companies to partner with

Indigenous Peoples on low-carbon projects

Shareholder dialogue

\section{ndigenous environmental stewardship}

What are the recommended next steps?

Where should they be implemented in the nvestment value chain?

Exploring the potential to fund Indigenous-led naturebased climate solutions

Direct investments by investors; asset managers have the onus to raise such investment opportunities and prospects with their clients

Encouraging portfolio companies to engage with Indigenous Peoples on environmental stewardship

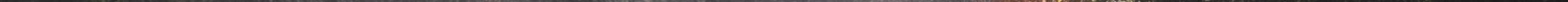




\section{Introduction}

Responsible investors can contribute to reconciliation in Canada by supporting the Indigenous economy. Channelling capital towards Indigenous capacity-building and well-being will benefit the entire Canadian

economy. Without inclusive growth, whose value is fairly distributed across society and creates opportunities for all, no sustainable development is possible (Organisation for Economic Co-operation and Development (OECD), 2018). Addressing inequalities in the allocation, distribution, and valuation of capital is necessary for such inclusion. Responsible investors worldwide have started to step in for such transformation, calling for changes in financial markets (Newswire, 2020).

Canadian responsible investors have the duty and responsibility to engage in the process of truth and reconciliation, as outlined in the Truth and Reconciliation Commission of Canada's Call to Action 92 on Business and Reconciliation (Truth and Reconciliation Commission of Canada, 2015). Yet Indigenous Peoples are still relatively invisible in Environmental, Social, and Governance (ESG) reporting and the investment chain. The report sheds light on this absence and outlines avenues for transforming RI practices towards reconciliation.

The relationships between Indigenous Peoples and RI are analyzed through the lens of six topics:

1. Recognition of Indigenous rights;

2. Diversity and inclusion (of Indigenous Peoples)

3. Building a thriving Indigenous economy through partnership;

4. Fiduciary duty and Indigenous Peoples;

5. Building an inclusive and just transition to a low-carbon economy through partnership; and,

6. Indigenous environmental stewardship

Canadian responsible investors show significant disparity when engaging with these topics. Indigenous rights and the broader issue of diversity and inclusion are relatively visible in the Canadian RI industry's discussions and occur across the investment chain. Building a thriving Indigenous economy through partnership, fiduciary duty and Indigenous Peoples, and transitioning to a low-carbon economy through partnership are discussed at some Rl industry events but are rarely included in the investment chain. Indigenous environmental stewardship is quasi absent from conversations.

The following sections elaborate on how the Canadian RI industry currently engages with each topic by mapping the topics on the investment chain. Throughout, the report offers practical recommendations for better including Indigenous Peoples in investment decision-making processes. Those incremental changes should be envisioned as the first steps towards reconciliation, but alone they are insufficient. Investors mus acknowledge and address the systemic discrimination that permeates the investment chain to support

inclusive growth. Transforming the structures of power and influence in place is necessary to this endeavour.
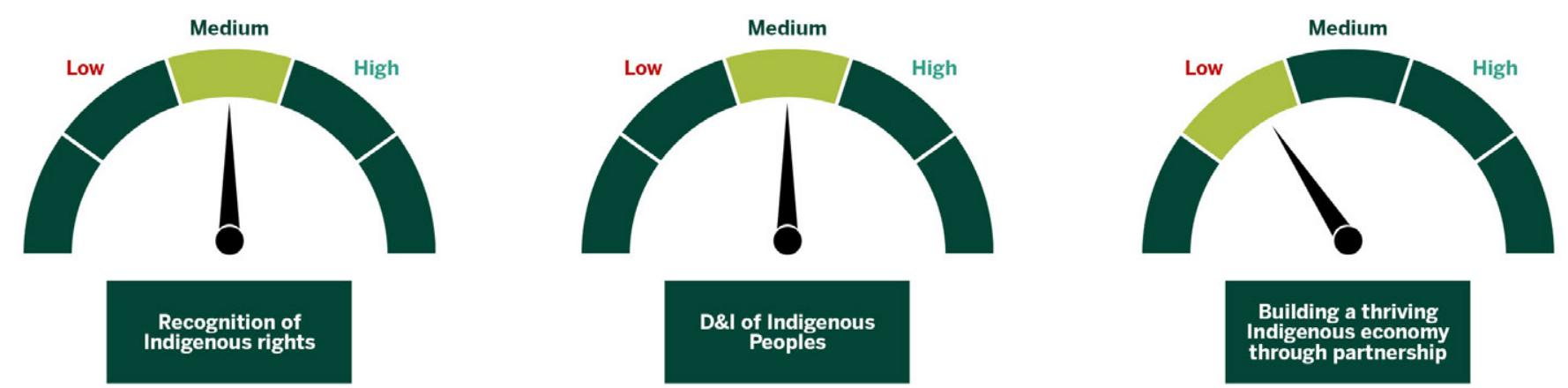

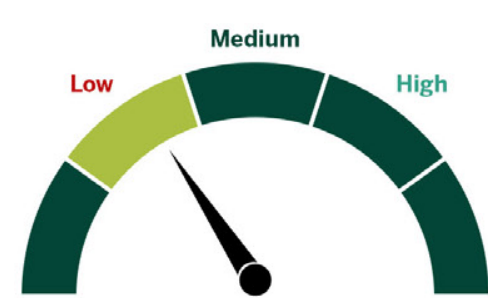

Fiduciary duty and
Indigenous Peoples

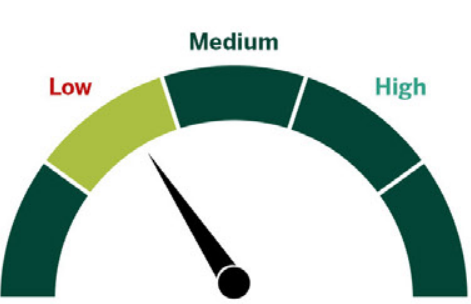

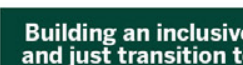

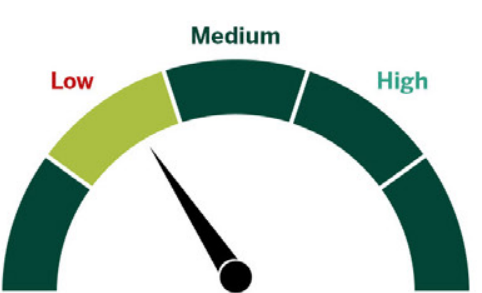

Indigenous
environmental
stewardship

Figure 3: Relative visibility of the six topics that relate to Indigenous Peoples in the Canadian Rl industry 


\section{Indigenous Peoples and ESG Reporting}

\section{THE ABSENCE OF INDIGENOUS PEOPLES IN INTERNATIONAL ESG REPORTING STANDARDS}

Responsible investors typically rely on international Environmental, Social, and Governance (ESG) reporting guidelines (e.g., SASB, GRI, AA1000, IICM, IIRC) to make investment decisions. These international ESG reporting ${ }^{3}$ guidelines are used by companies to disclose their ESG performance usually on an annual basis. However, such guidelines do not mention Indigenous Peoples, except for the Global Reporting Initiative (GRI) ${ }^{4}$ and Sustainability Accounting Standards Board (SASB) ${ }^{5}$. This deficiency is conducive to the absence of

Indigenous Peoples in ESG practices and discussions. Since there is no disclosure from the corporate side to investors, Indigenous issues remain invisible.
INDIGENOUS RIGHTS IN GRI AND SASB

\section{GRI Disclosure 411-1}

Incidents of violations involving rights of Indigenous Peoples

The reporting organization shall report the following information:

a) Total number of identified incidents of violations involving the rights of Indigenous Peoples during the reporting period

b) Status of the incidents and actions taken regarding the following:

i. Incidents reviewed by the organization

ii. Remediation plans being implemented

iii. Remediation plans that have been implemented, with results reviewed through routine internal management review processes

iv. Incident no longer subject to action

\section{SASB - Oil \& Gas - Exploration \& Production}

- EM-EP-210a.2. Percentage of (1) proved and (2) probable reserves in or near Indigenous land

- EM-EP-210a.3. Discussion of engagement processes and due-diligence practices with respect to human rights, Indigenous rights, and operation in areas of conflict

The GRI Guidelines ${ }^{6}$ - based on their latest Guidelines, the GRI Standards - consider Indigenous issues only from a legal and financial risk perspective (i.e., 411- Rights of Indigenous Peoples, 412 - Human Rights Assessment, 413 - Local Communities). In the indicator GRI 411- Rights of Indigenous Peoples, the management approach disclosures include reference to due diligence to avoid infringing on rights of Indigenous Peoples and Free, Prior, and Informed Consent (FPIC).

SASB provides industry-specific references (i.e., Oil and Gas, Metals and Mining, Forestry, and Logging) to the UNDRIP and FPIC, covering disclosures on engagement processes and due-diligence practices concerning human rights, Indigenous rights, and operations in areas of conflict.

3 Extra-financial reporting and sustainability reporting are also used to describe this type of reporting by companies

4 https://www.globalreporting.org/standards/, accessed 21 June 2021.

5 https://www.sasb.org/, accessed 21 June 2021. 
While these guidelines include disclosures on due diligence and engagement processes on Indigenous rights, they do not offer guidance on how improving those processes (i.e., how companies can engage with Indigenous Peoples to better report their business impacts on Indigenous communities). Responsible investors depen on what companies disclose in their ESG reporting or on their interpretation of what is best for Indigenous Peoples. Such an approach is antithetical to the process of truth and reconciliation that instead supports the self-determination of Indigenous communities.

In 2020, discussions about the possibility of creating a unique international ESG standard to limit reporting fatigue from companies emerged from various international reporting organizations. Yet Indigenous Peoples have been absent from those conversations. Additionally, discussions have revolved around the concept of financial materiality and the need to decrease the companies' due-diligence efforts (see Cho, 2020; Eccles et al., 2012; Guillot \& Hales, 2021), leaving behind essential metrics like social issues and impacts of companies on local communities, human rights, land ownership and so forth. Such focus is unlikely to encourage investors - or companies - to engage with Indigenous Peoples. In 2021, there was still no explicit legal obligation for investors to respect the UNDRIP, despite the official commitment of Canada on this matter.

Meanwhile, the Principles for Responsible Investment (PRI) association identifies the protection of Indigenous Peoples' rights, including the right to self-determination and the right to cultural life, as crucial indicators of impacts of value chains on human rights (PRI, 2018). The PRI is the world's leading proponent of responsible investment, whose 3,308 signatories (i.e., asset owners, investment managers, and service providers) represent US $\$ 103.4$ trillion-worth of assets under management (PRI, 2020). The PRI also encourages its signatories to engage with Indigenous issues and perspectives through initiatives on deforestation (e.g., PRICeres Investment Initiative for Sustainable Forests) and human rights in the extractive sector (Nabylah Abo et al., 2020). The PRI classifies deforestation in the Amazon as not just an environmental issue, but a social one that threatens the livelihoods of Indigenous Peoples.

There is a misalignment between investor practices, companies reporting, and ESG reporting, and a growing recognition that Indigenous Peoples should be included in formulating investment practices. This discrepancy contributes to the relative invisibility of Indigenous Peoples in the Canadian RI industry's discussions and practices.

\section{INDIGENOUS PEOPLES}

The language used to engage with Indigenous Peoples frames our thinking. In Canada, the term 'Aboriginal' had been used synonymously with 'Indigenous' to collectively refer to the First Nations, Inuit, and Métis peoples. Understanding the etymology of both terms provides insights into why the term 'Indigenous' is preferable to 'Aboriginal.' In Latin, the prefix 'ab' means "not" or "away from," which contradicts what the term is supposed to encapsulate. The term Indigenous, derived from the Latin word 'indigena,' means "sprung from the land; native" and has become a worldwide standard term since the United Nations Declaration on the Rights of Indigenous Peoples (2007). Using the word 'Indigenous Peoples' over 'Aboriginal' alludes to the existence of distinct peoples, which reflects the reality of separate nations with diverse cultures. When referring to Indigenous Peoples specifically rather than as a collective whole, one should refer to a Nation in its terminology to respect its rights to self-identity. The term 'Indian' referred to First Nations in Canada. This term is no longer used as its colonial origins are offensive. It is still employed to describe First Nations persons' legal status under the Indian Act (1876).

\section{RECONCILIATION}

Reconciliation is the process of acknowledging the historical injustices done unto Indigenous Peoples. It attempts to repair relationships damaged by years of mistrust and exploitation. Reconciliation should not concern Indigenous Peoples alone; instead, it involves relationship-building efforts from Indigenous and non-Indigenous Peoples. In reconciliation, the role of Indigenous Peoples is to bring forward the emotional elements of past traumas and be ready for forgiveness. For non-Indigenous Peoples, reconciliation involves a process of learning about the past and present relationships between Indigenous Peoples and the settler society, understanding the ongoing impacts of colonization, and utilizing Western privilege to challenge dominant social structures and thought processes.

\section{DECOLONIZATION}

Decolonization is the process of unlearning colonial biases and ideologies that inhibit Indigenous perspectives and ways of life. It involves deconstructing the societal structures that perpetuate the superiority of Western thought to allow for the promotion of Indigenous ideals. Decolonization involves rethinking our biases and assumptions regarding Indigenous Peoples and their cultures individually.

\section{INDIGENIZATION}

Indigenization is a process of normalization of Indigenous knowledge systems. Indigenization is not merely the replacement of a Western way of thinking with an Indigenous way, but rather the integration of the two knowledge systems in a way that allows mutual understanding and appreciation of both ways of life. 


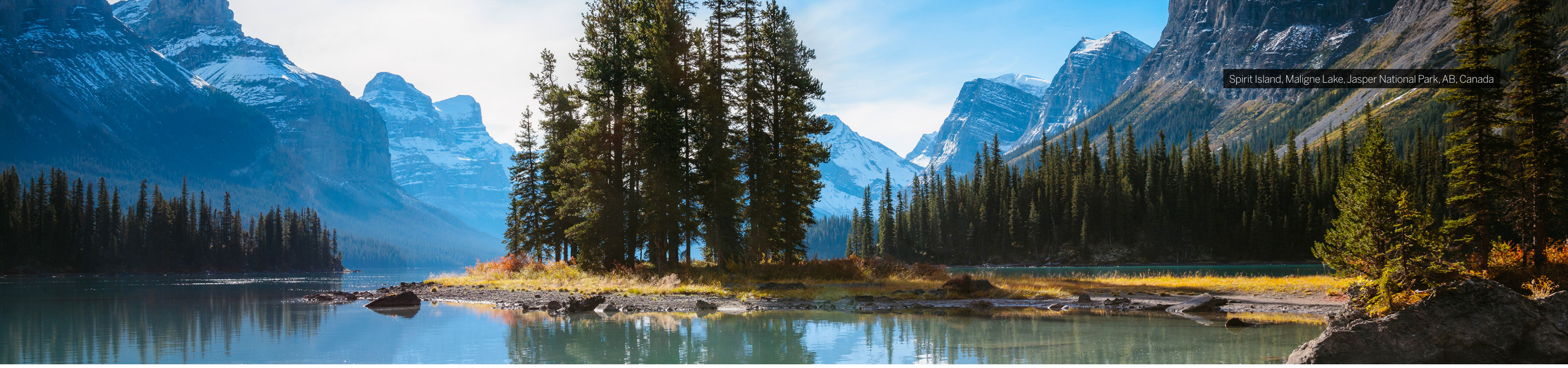

\section{RECENT INITIATIVES IN THE CANADIAN RESPONSIBLE INVESTING INDUSTRY TO INCLUDE INDIGENOUS PEOPLES}

In Canada, obtaining a Social License to Operate (SLO) from Indigenous Peoples is becoming increasingly essential to undertake projects or corporate activities that impact Indigenous communities. An SLO combines social legitimacy, credibility, and trust (Raufflet et al., 2013). The concept of SLO is closely related to the requirement of the FPIC but differs on some key points:1) SLO usually involves an ongoing process not just before, but also during ongoing operations; 2) SLO is considered the responsibility of companies while the FPIC is considered more of a responsibility of states.

Earning the consent of Indigenous Peoples is a necessary process that should not be taken lightly. Yet, by focusing on SLOs, Canadian responsible investors have envisioned their interactions with Indigenous Peoples mainly through the lens of risk management. Although crucial, the sole focus on risks limits the opportunity for investors to partner with Indigenous Peoples and contribute to reconciliation.

In 2018, SHARE (Shareholder Association for Research and Education) and NATOA (National Aboriginal Trust Officers Association) joined their efforts to create the Reconciliation and Responsible Investment Initiative $(\text { RRII) })^{8}$. The RRII has been spearheading the efforts to integrate reconciliation and responsible investment. It engages with investors to promote positive economic outcomes for Indigenous Peoples through increased partnerships and respect for Indigenous rights and title. The RRll's approach is based on the Truth and Reconciliation Commission's Principles of Reconciliation and Call to Action 92.

In 2020, the Responsible Investment Association (RIA) of Canada, the industry association for responsible investment, led an initiative to lead investors managing more than $\$ 4$ trillion in assets to sign a statement to make commitments to promote Diversity \& Inclusion across their organizations and portfolio companies. In addition to the statement, RIA also organized a Diversity \& Inclusion week from October 26-30, 2020, which included impact investing in Indigenous Entrepreneurship and Innovation and Shareholder Engagement for Advancing Diversity \& Inclusion

Despite those recent initiatives, few Canadian RI policies or reports of institutional investors make references to Indigenous Peoples. They are typically included in the topic of human rights as a social ('S') issue. The 'E' and ' $G$ ' of ESG generally lack references to Indigenous Peoples. The classification of Indigenous rights in ESG practices, such as recognizing the FPIC, varies. For instance, most investors categorize Indigenous rights under a social ('S') issue because of its similarity with human rights issues. However, the lack of recognition of international agreements recognizing Indigenous rights (i.e., UNDRIP) and the limited engagement with Indigenous communities potentially leading to an absence of SLO could also be classified as a governance ('G') problem. Furthermore, Indigenous communities are stewards of the land and worldwide guardians of biodiversity. With their role in land protection and preservation, Indigenous themes could also be classified under environmental ('E') issues. Due to their multiple roles in Canadian society, Indigenous issues and perspectives cannot be classified under one single letter of ESG. The difficulty of fitting existing Western categories contributes to the lack of Indigenous perspectives in formulating and applying ESG criteria. 'I' remains invisible in ESG (Podlasly et al., 2021). 


\section{Recognition of Indigenous Rights}

\section{WHAT DOES IT MEAN TO RECOGNIZE INDIGENOUS RIGHTS?}

Indigenous rights are enshrined in the United Nations Declaration on the Rights of Indigenous Peoples (UNDRIP), a resolution adopted by the United Nations in 2007, and its articles on the Free, Prior, and Informed Consent (FPIC). The FPIC is a term used to describe the right of Indigenous Peoples to offer or withhold consent to developments that may impact their territories or resources. Recognition of Indigenous rights implies affirmation and support for the UNDRIP and FPIC.

\section{WHY IS THIS TOPIC IMPORTANT?}

Recognition of Indigenous rights is the first step towards building relationships with Indigenous Peoples and achieving reconciliation. The FPIC of Indigenous communities is essential to undertake projects or corporate activities that directly impact Indigenous Peoples. This topic is particularly relevant in extractive industries that affect lands for which Indigenous Peoples are the stewards. Yet, the FPIC is not an obligatory checklist for investors and their portfolio companies to obtain their SLO. Recognition of Indigenous rights as per the international framework of the UNDRIP should support investor engagement with Indigenous Peoples in a broad range of topics beyond the FPIC
NEI Focus List 2021

"Indigenous rights will continue to be a core focus for our engagement with companies in the extractives sectors (and the banks that finance them), where projects often overlap with the traditional territories of Indigenous groups. While the conversation still focuses on the risks associated with getting Indigenous engagement wrong, the conversation is increasingly turning to the opportunities to do it right. Future success will, in part, be dictated by the ability of companies to create real and equitable partnerships with Indigenous groups.

While the conversation still focuses on the risks associated with getting Indigenous engagement wrong, the conversation is increasingly turning to the opportunities to do it right.

We first articulated our support for the concept of free, prior, and informed consent (FPIC) in 2008 and have pushed companies to internalize this best practice ever since. Those companies that have genuinely adopted FPIC into their engagement process are well-positioned to thrive as we see governments in Canada start to make their adoption of the UN Declaration on the Rights of Indigenous Peoples (UNDRIP) real." (NEI Investments, 2021, p. 7)

British Columbia Investment Management Corporation (BCl)

ESG Annual Report

Consultation with Indigenous Communities is referenced under Human Rights, which is a priority engagement topic under $\mathrm{S}$ of the ESG:

"Engaging on human rights can focus on a variety of stakeholders and issues, ranging from employee health and safety, consumer rights and product safety, labour standards, consultation with Indigenous communities, social and environmental impacts on local communities, stakeholder engagement, and others." (British Columbia Investment Management Corporation (BCI), 2019, p. 19)

\section{VISIBILITY OF THIS TOPIC IN THE INVESTMENT CHAIN}

Recognition of Indigenous rights is primarily visible through shareholder engagement, meaning during private discussions between investors and portfolio companies. This topic becomes publicly visible when the dialogue fails and turns into shareholder proposals filed by investors. Such submissions typically request companies to identify and address the risks linked to the non-respect of Indigenous rights (and provide a report on these issues to shareholders) and respect the UNDRIP and FPIC in their direct operations. 
EXAMPLES OF SHAREHOLDER PROPOSALS ON INDIGENOUS RIGHTS

\section{INDIGENOUS RIGHTS AT THE BANK OF NOVA SCOTIA}

For three years in a row (2018-2020). Harrington Investments filed a shareholder proposal at the Bank of Nova Scotia (TSX: BNS) requesting the bank to revise its Human Rights policies to thoroughly consider the borrowers' policies and practices for potential impacts on human and Indigenous Peoples' rights, including respect for the FPIC of Indigenous communities in all its project finance and commercial lending activities. In 2020, the proposal received 8.89 per cent of votes at the annual general meeting (AGM). (RRII, 2020; SHARE, 2020)

\section{INDIGENOUS POLICIES AT TC ENERGY CORP}

In March 2019, the United Church of Canada Pension Fund filed a shareholder proposal at erstwhile TransCanada requiring clear and comprehensive information about the company's policies, practices, and performance on Indigenous rights and relations to assess risk and stability and analyze future performance. The proposal received 10.21 per cent of votes at the AGM. (SHARE, 2019)

\section{DIVERSITY AND INCLUSION OF INDIGENOUS PEOPLES AT FIRSTSERVICE CORPORATION}

Compensation Employees' Union Surplus Fund filed a proposal at FirstService Corp requesting that the Board of Directors adopt and publish a formal, written Board diversity policy by December 2018, recognizing Indigenous heritage as a diversity criterion. (SHARE, 2018b)

\section{DUE DILIGENCE PROCESS AT FIRST QUANTUM MINERALS LIMITED}

The Fonds de solidarité des travailleurs du Québec (FTQ) (Filer) and the United Church of Canada Pension Plan (Co-Filer) filed a proposal at First Quantum Minerals Limited requesting the Board of Directors to detail the due-diligence process used to identify and mitigate risks from human rights, including those of Indigenous communities. The proposal was withdrawn before the AGM (SHARE, 2018a)

\section{DUE-DILIGENCE PROCESS AT ENBRIDGE INC}

The Sisters of Charity (Halifax) filed a proposal requesting the Board of Enbridge Inc to prepare a report to shareholders at a reasonable cost and omitting proprietary information, detailing the due-diligence process used by Enbridge, its affiliates, and subsidiaries to identify and address social and environmenta risks, including Indigenous rights risks, when reviewing potential acquisitions. The proposal received a 30.08-per-cent vote at the AGM. (SHARE, 2018a)

Recognition of Indigenous rights is also visible in the Indigenous policies of portfolio companies, especially in the extractive sector.
EXAMPLE OF INDIGENOUS ENGAGEMENT POLICY BY A PORTFOLIO COMPANY

\section{TECK RESOURCES - INDIGENOUS PEOPLES POLICY}

Teck engages with Indigenous Peoples potentially affected by our activities to:

- Build respectful relationships through early, inclusive dialogue and collaborative processes.

- Provide resources to build the capacity of both Indigenous Peoples and Teck for meaningful dialogue.

- Integrate Indigenous Peoples' perspectives and traditional knowledge into company decisionmaking throughout the mining life cycle to enhance benefits and address impacts.

- Work to achieve the free, prior, and informed consent of Indigenous Peoples when proposing new or substantially modified projects.

- Work with Indigenous Peoples to achieve self-defined community goals that provide lasting benefits. (Teck, 2021)

\section{LIMITATIONS OF THE CURRENT TREATMENT OF THIS TOPIC IN THE \\ INVESTMENT CHAIN}

Over the past five years, shareholder proposals submitted to AGMs have increased and received a larger support through proxy voting (e.g., higher support rate in votes favourable to the proposals) (Mueller \& Ising, 2017). Shareholder proposals became popular through media attention. In recent years, the attention has shifted from governance (2017-2018) to climate change issues: a new engagement priority for 73 per cent of Canadian investors. This was followed by Diversity and Inclusion (32 per cent) and ESG Disclosure (28 per cent) (Nabylah Abo et al., 2020).

Shareholder proposals are non-binding. Therefore, even though a proposal receives a majority voting, they are still mere suggestions to the boards of directors. Good governance would require the board to take the suggested course of action; however, it is not the case legally.

Shareholder proposals filed at Canadian corporations on Indigenous rights have received a meagre support rate (with a few notable exceptions). Canadian investors leading those actions lack explicit support from their fellow shareholders. In 2017, the Dakota Access Pipeline project was a controversial matter that gained a lot of media traction, mainly around Indigenous land issues, rights, and social license to operate. Shareholders of Enbridge Inc., Canada's largest natural gas distribution provider, became concerned over infringement of the rights of Indigenous Peoples and their lands. They received 30-per-cent favourable votes for their proposal, asking the corporation to assess the impact of Indigenous rights (SHARE, 2017). Shareholders must often submit the same proposals several times to get a majority voting or an agreement with the board of directors. In 2020, known to have been an exceptional year for social issues, only 16 shareholder proposals related to social and environmental issues among the hundreds of shareholder proposals filed in the American market gathered a majority of votes (Orowitz \& Rosati, 2021). 


\section{RECOMMENDED NEXT STEPS}

Recommended next steps for recognizing Indigenous rights across the investment chain include:

- Investors referencing the UNDRIP as the international framework for Indigenous rights and committing to respect Indigenous rights in Investment Policy Statements and proxy-voting guidelines through collaboration with asset managers:

Investors implementing due-diligence processes in decision-making to assess actual or potential negative impacts of sectors, companies, and projects on Indigenous Peoples' rights; and,

- Investors communicating their expectations to portfolio companies and projects on the FPIC, particularly where adverse impacts on Indigenous Peoples' rights have occurred.

\section{RATIONALE FOR NEXT STEPS}

Recognition of Indigenous rights is the first step for investors and their portfolio companies towards building relationships with Indigenous Peoples. In June 2021, Bill C-15, which aims to harmonize Canadian laws with the UNDRIP, was passed by the Senate. With the adoption of the UNDRIP at a federal level (British Columbia adopted UNDRIP in November 2019), this topic demands inclusion across the entire investment chain.

Including this topic in investment policy statements, investment management agreements, and ongoing management of portfolio companies would help:

- Pave the path for direct investor engagement with Indigenous Peoples;

- Provide clear mandates for investment managers to respect rights in the investment due-diligence process and proxy-voting guidelines:

- Prevent violation of Indigenous rights by portfolio companies; and,

- Effect improvements in portfolio companies' policies on Indigenous rights, thereby enabling collaborative relations with Indigenous Peoples in other areas.
RECOGNITION OF INDIGENOUS RIGHTS AND INVESTMENT CHAIN

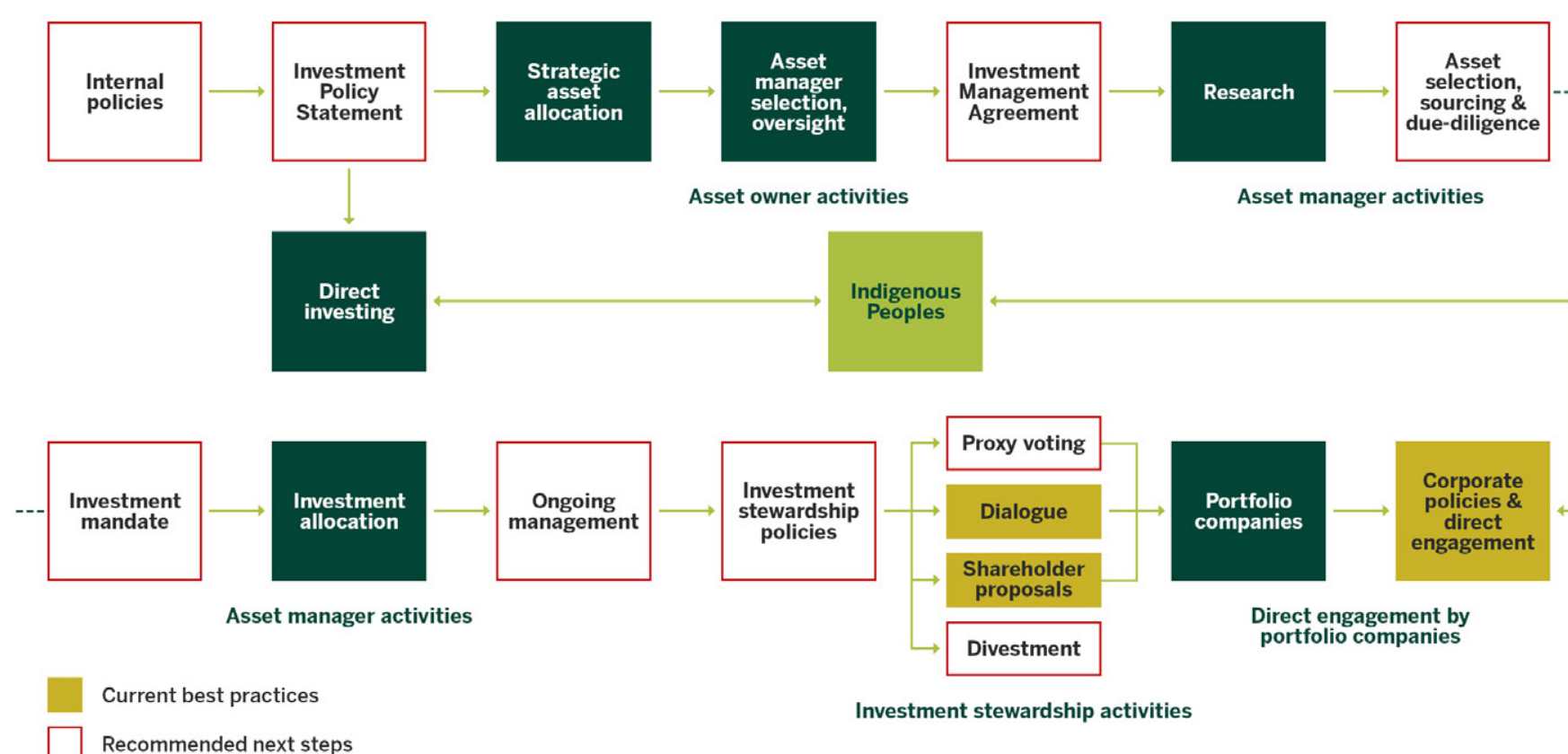

Figure 4: Recognition of indigenous rights and investment chain
Investment stewardship activities 


\section{Diversity and Inclusion (of Indigenous Peoples)}

\section{WHAT DOES IT MEAN TO HAVE DIVERSITY AND INCLUSION (OF INDIGENOUS PEOPLES)?}

Diversity and inclusion mean creating a space for and acknowledging the benefit of having a range of perspectives in decision-making. Diversity and inclusion of Indigenous Peoples in corporate Canada refer to the proportional representation of Indigenous Peoples across all employee and executive management levels and boards of directors. Furthermore, diversity and inclusion provide an opportunity to put forward policies that promote intersectionality among Indigenous communities in various corporate policies. Intersectionality is a perspective that explores the interactions of social markers such as race, class, gender, age, and sexual orientation that shape an individual's or group's experience (Collins, 2000; Yuval-Davies, 2006). Embracing intersectionality could foster the presence of two-spirited (2S) beings, Indigenous women, and Indigenous youth in the Canadian corporate decision-making process; thus, broadening the concept of diversity too often limited to (White) women (Osipovich \& Otani, 2020; Rosenblum, 2020)

\section{WHY IS THIS TOPIC IMPORTANT?}

Indigenous Peoples are severely underrepresented in boards of directors across corporate Canada. In 2016 Indigenous Peoples represented 4.9 per cent of Canada's population. Based on the 2020 amended disclosures provided by 213 publicly traded corporations governed by the Canada Business Corporations Act (CBCA), Indigenous Peoples only accounted for 0.5 per cent of board positions. On the other hand, visible minorities ${ }^{10}$. who accounted for 22.3 per cent of Canada's population in 2016, made up 5.5 per cent of the board positions. There is an opportunity to leverage the current momentum on diversity and inclusion to get a proportional representation of Indigenous Peoples across corporate Canada.

\section{VISIBILITY OF THE TOPIC IN THE INVESTMENT CHAIN}

Diversity and inclusion are visible in the recent pledge signed by Canadian investors, where they explicitly acknowledged racism against Black and Indigenous Communities and People of Colour (BIPOC). Responsible investors also pledged to take intentional steps to promote diversity and inclusion in their organizations and portfolio companies. This is key as a recent survey from equity organization Catalyst Canada indicated that 52 per cent of 86 per cent Indigenous People surveyed are "on guard" at work, and about 60 per cent feel psychologically unsafe on the job (Thorpe-Moscon \& Ohm, 2021)

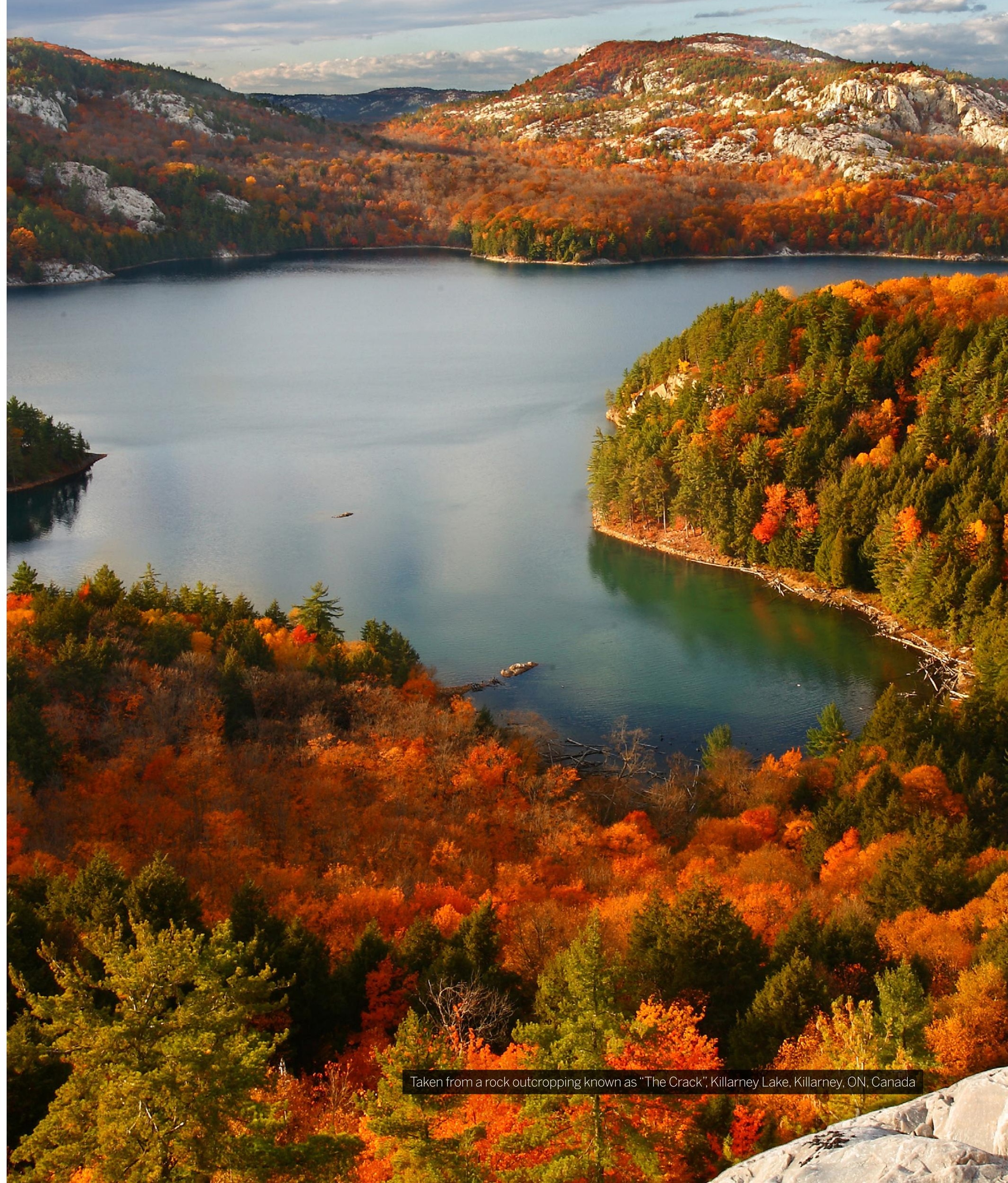




\section{DIVERSITY AND INCLUSION AT CAMECO}

Cameco, a leading global uranium producer, has a board of directors' diversity commitments across five areas of skills, backgrounds, experience, age, and gender representation:

- At least one Indigenous director from Saskatchewan;

Directors with extensive experience in geographical areas where Cameco has or anticipates significant business interests:

\section{- At least 30 per cent of directors are women:}

- Directors of various ages; and,

- Directors with differing backgrounds and experience.

Cameco is a significant employer of Indigenous Peoples, who make up more than 45 per cent of its workforce in northern Saskatchewan operations (Cameco, 2021).

Based on a report on the review of disclosures related to business and reconciliation by corporate Canada published by the RRII (Wheatley \& Lau, 2021), corporate policies related to Indigenous diversity and inclusion have improved from 2016 to 2019. While the number of policies on the inclusion of Indigenous Peoples in the board of directors and senior management saw a significant increase, the number of general employment policies on Indigenous inclusion is still low.

\section{DIVERSITY POLICIES IN CORPORATE CANADA}

SHARE published a report on the progress on the performance of business and reconciliation by corporate Canada by analyzing public disclosures of 78 TSX-listed Canadian companies across eight sector indices (Financial, Healthcare, Consumer Discretionary, Capped Consumer Staples. Capped Energy, Capped Materials, Capped Renewable Energy and Clean Technology, and Capped Telecommunications)

The following table provides the number of analyzed companies (out of 78) with Indigenous diversity and inclusion policies (Vs. 2016). Although progress has been made, only 28 per cent of companies have developed policies aiming at more diversity and inclusion (Wheatley \& Lau, 2021, p. 35).

\begin{tabular}{|l|l|l|}
\hline & 2016 & 2019 \\
\hline Board of Directors Diversity Reference & 0 & 22 \\
\hline Board Member Metric & 0 & 22 \\
\hline Senior Management Diversity Reference & 0 & 17 \\
\hline Employee Diversity Reference & 9 & 11 \\
\hline Employee Diversity Target & 1 & 1 \\
\hline
\end{tabular}




\section{LIMITATIONS OF THE CURRENT TREATMENT OF THIS TOPIC IN THE INVESTMENT CHAIN}

The term BIPOC gained wide traction since May 2020 as part of the Black Lives Matter movement. Founders of the "BIPOC Project" use the term to "highlight the unique relationship to Whiteness that Indigenous and Black people have, which shapes the experiences of and relationship to white supremacy for all people of colour within a U.S. context" (The BIPOC Project, 2020)

While the term BIPOC applies to the realities of the American society, it does not adequately reflect the reality of the Canadian society, where Francophones (among others) are also part of the minorities. As the RI industry adopts this term for driving the Diversity and Inclusion agenda, it is important to remember that the challenges faced by Indigenous Peoples are very distinct from other minority groups due to the long history of colonialism. genocide, and racism faced by Indigenous Peoples (Thorpe-Moscon \& Ohm, 2021). Grouping Indigenous Peoples and other visible minorities into one category could impede significant progress on Indigenous representation and inclusion. In addition, a broad classification does not enable investors to tackle specific difficulties linked to intersectionality (e.g., Indigenous women and girls). Having diversity and inclusion policies specifically for Indigenous Peoples in alignment with the principles of reconciliation could help address the unique situation of Indigenous Peoples.

There is also a lack of data points on the representation of visible minorities for investors to assess a company's performance on diversity and inclusion. Additionally, while disclosure is necessary, it is not sufficient to achieve diversity and inclusion. Public statements and targets, including concrete measures to achieve them, could contribute to change. ${ }^{11}$ The Canadian RI industry can collaborate with portfolio companies to adopt effective measures and broaden the understanding and implementation of diversity and inclusion.

\section{RECOMMENDED NEXT STEPS}

Recommended next steps for incorporating diversity and inclusion (of Indigenous Peoples) across the investment chain include:

- Investors and asset managers increasing Indigenous cultural awareness and sensitivity training for their employees and influencing their portfolio companies to do the same; and

- Investors collaborating with their portfolio companies to set up comprehensive policies on Indigenous representation among employees, senior management, and boards. These policies can later spur investment due diligence.

\section{RATIONALE FOR NEXT STEPS}

- Identifying barriers to proportional Indigenous representation across the workforce:

- Collaborating between investors and portfolio companies to develop comprehensive policies for Indigenous representation:

- Setting and adhering to targets on Indigenous representation

- Representing of Indigenous Peoples in the Board of Directors, leading to inclusive governance; and,

- Creating robust data collection across portfolio companies to be used in the investment due-diligence process.

The incorporation of diversity and inclusion has been limited to improving the gender diversity of boards. However, the broader sense of diversity and inclusion, including notions of BIPOC and intersectionality, are still in a nascent stage. Progressing towards the next phase requires collaborative solutions. Therefore, as a next step, diversity and inclusion could be applied in investment stewardship policies, which govern ongoing portfolio management activities.

\section{DIVERSITY AND INCLUSION (OF INDIGENOUS PEOPLES) AND} INVESTMENT CHAIN
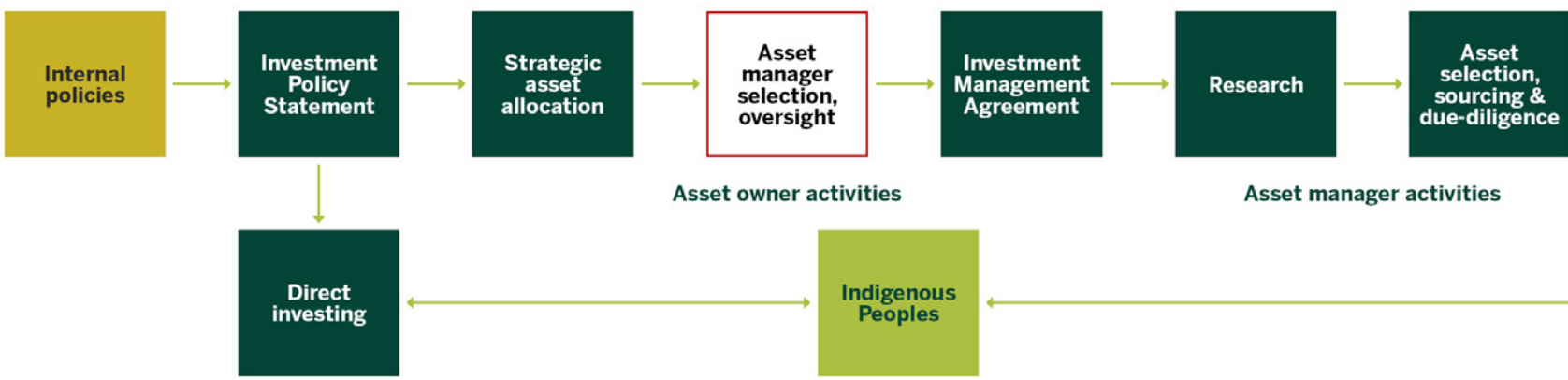

Asset owner activities

Asset manager activities
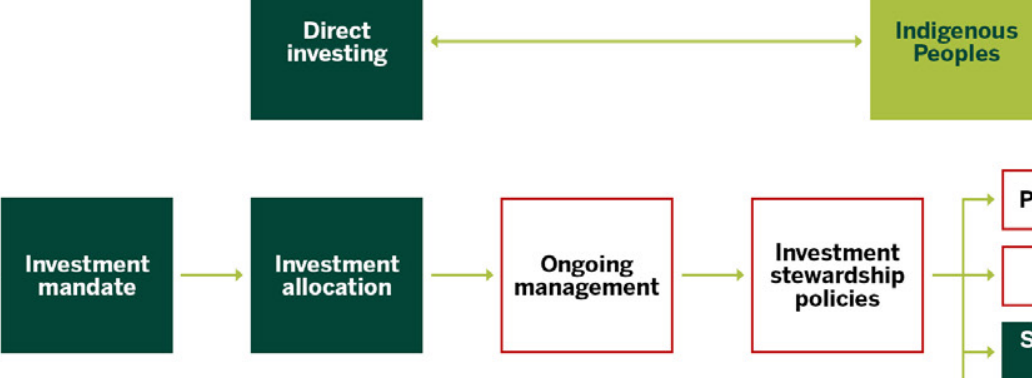

Asset manager activities

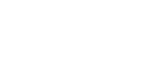

Current best practices

$\square$ Recommended next steps

Figure 5: Diversity and inclusion (of indigenous peoples) and investment chain

11 RIA D\&I Week, Wednesday, Oct 28 - D\&l in Your Portfolio, Shareholder Engagement for Advancing Diversity \& Inclusion, authors' field notes. 


\section{Building a Thriving Indigenous Economy Through Partnership}

\section{WHAT DOES IT MEAN TO PARTNER IN BUILDING A THRIVING INDIGENOUS ECONOMY?}

The Indigenous economy is the combined income across Indigenous households, businesses, and government sectors - estimated at $\$ 32$ billion in 2016. The Indigenomics Institute, a platform for rebuilding and designing Indigenous economies, envisions the potential for this economy to grow to \$100Bn (Gulati \& Burleton, 2011).

Investors and their portfolio companies could contribute to the Indigenous economy by partnering with Indigenous Peoples in four key areas: procurement, access to capital, capacity development, and wealthsharing. Procurement is a crucial driver for Indigenous economic growth through its revenue for Indigenous businesses and the relationships formed through corporations establishing procurement agreements. Improving access to capital for Indigenous organizations, such as the Aboriginal Financial Institutions (AFIs) and First Nations Finance Authority (FNFA), would help scale up Indigenous businesses and governments. Capacity development would enhance Indigenous access to business training, internships, scholarships, and participation of Indigenous students in post-secondary education. Finally, wealth sharing can be achieved by increasing Indigenous equity participation in resource-development projects.

\section{WHY IS THIS TOPIC IMPORTANT?}

There are significant socioeconomic gaps between Indigenous and non-Indigenous Peoples in Canada. As per the 2016 Census of Population, 24 per cent of Indigenous Peoples living in urban areas in the provinces were in poverty, compared with 13 per cent of non-Indigenous Peoples in poverty in those areas. The incidence of poverty is higher among the Indigenous youth and children younger than 18, with 30 per cent living in poverty in an urban area (Statistics Canada, 2020).
The growth of the Indigenous economy is critical to support Indigenous self-determination, which includes the right to freely pursue economic, political, social, and cultural development (Department of Justice, 2017). Supporting the Indigenous economy is conducive to a thriving Canadian economy. Such change cannot be achieved without leveraging capital from investors and collaborating with corporate Canada on capacity development, procurement, and wealth sharing.

\section{VISIBILITY OF THIS TOPIC IN THE INVESTMENT CHAIN}

According to a report on the progress on the performance of business and reconciliation by corporate Canada by SHARE, only nine of the 78 surveyed companies disclosed information on Indigenous contracting and procurement, with 18 disclosing qualitative information. Indigenous-led organizations such as the Canadian Council for Aboriginal Business (CCAB), National Aboriginal Capital Corporations Association (NACCA), Aboriginal Financial Institutions (AFIs), and the Indigenomics Institute have been actively engaged in initiatives to collaborate with corporate Canada to promote Indigenous procurement and capacity development.

Procurement and capacity development also became visible in shareholder engagement and proxy voting through the historic shareholder support for a shareholder proposal on reconciliation and Indigenous economic advancement filed at the TMX Group Annual General Meeting 2021.

Direct investments such as Indigenous-led and Indigenous-focused investment products and funds like the FNFA bonds and Raven Indigenous Impact Fund can support access to capital and wealth sharing. These instruments have begun to gain significant traction among institutional investors.

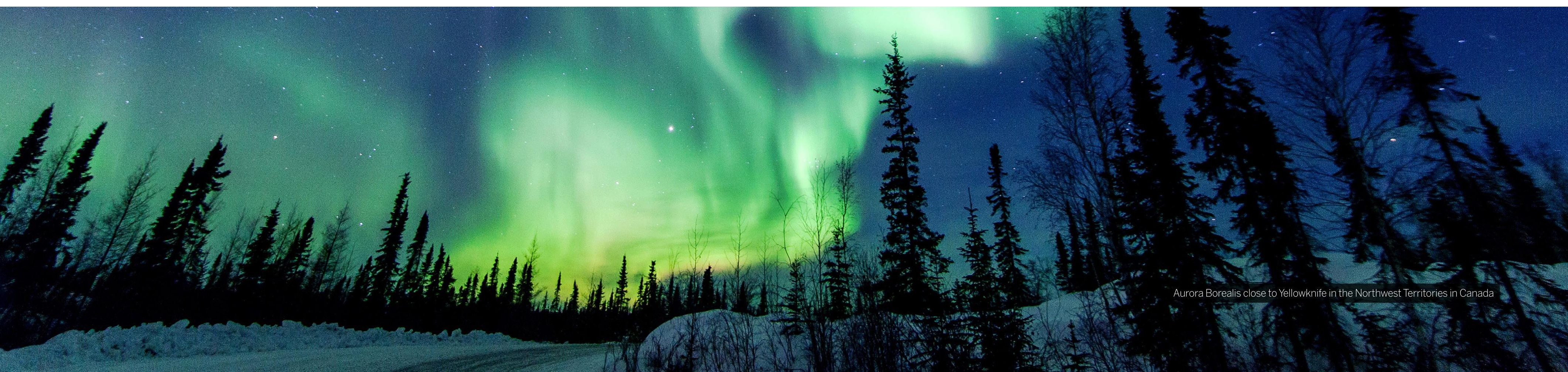


EXAMPLE OF SHAREHOLDER PROPOSAL ON INDIGENOUS ECONOMIC ADVANCEMENT

INDIGENOUS INCLUSION AT THE TMX GROUP

In May 2021. SHARE filed a shareholder proposal on behalf of the Atkinson Foundation at the TMX Group (TSX:X). The proposal requested the group's Board of Directors to report to shareholders on internal programs and policies on equity, diversity, and inclusion procurement from Indigenous-owned businesses, including support for capacity-building activities.

The proposal was voted nearly unanimously by the shareholders of the TMX Group, making it the first such proposal to be passed on Indigenous inclusion with potential knock-on effects across the Canadian capital markets (SHARE, 2021: Trichur, 2021).

\section{LIMITATIONS OF THE CURRENT TREATMENT OF THIS TOPIC IN THE \\ INVESTMENT CHAIN}

While procurement and capacity development are visible in corporate and responsible investment policies, the potential for investors to directly engage with Indigenous organizations and governments to provide funding for equity participation in projects across sectors of mutual interest, such as infrastructure, has not been fully explored. This limits the progress on partnership in areas of access to capital and wealth sharing.

\section{RECOMMENDED NEXT STEPS}

Recommended next steps for recognizing Indigenous rights across the investment chain include:

Asset managers and investors considering investments in existing impact investing products and collaborating on creating new investable products that benefit Indigenous Peoples; and

- Investors providing capacity development by offering due-diligence support to Indigenous investors.

\section{RATIONALE FOR NEXT STEPS}

Improving access to capital and wealth sharing would help:

- Unlock the full potential of Indigenous businesses; and,

- Increase Indigenous equity participation in resource development and infrastructure projects, which would significantly improve the socioeconomic status of Indigenous communities participating in those projects.
BUILDING A THRIVING INDIGENOUS ECONOMY THROUGH PARTNERSHIP ACROSS INVESTMENT CHAIN

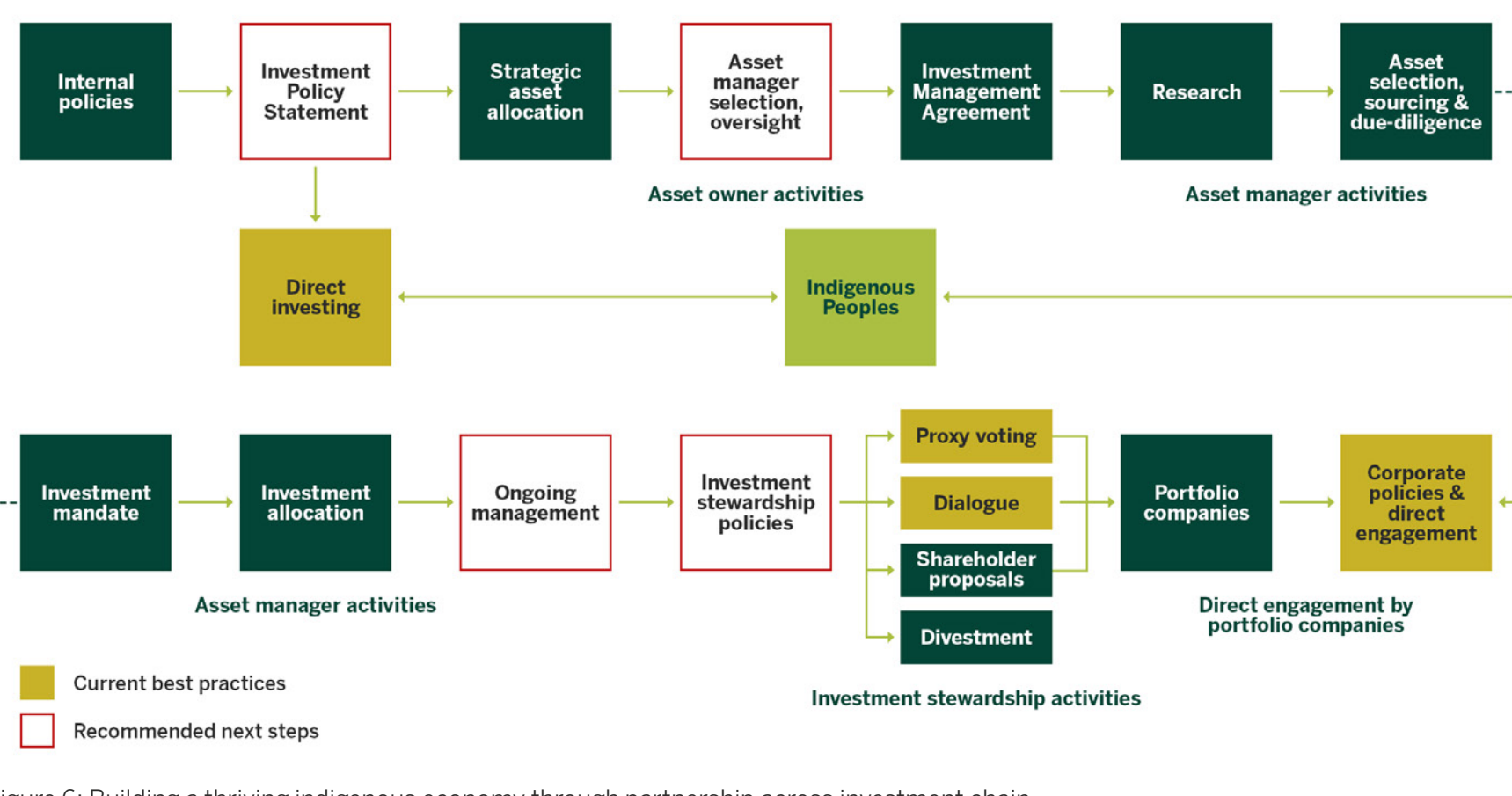

Figure 6: Building a thriving indigenous economy through partnership across investment chain

\section{BUILDING A THRIVING INDIGENOUS ECONOMY THROUGH} PARTNERSHIP: DIRECT INVESTING

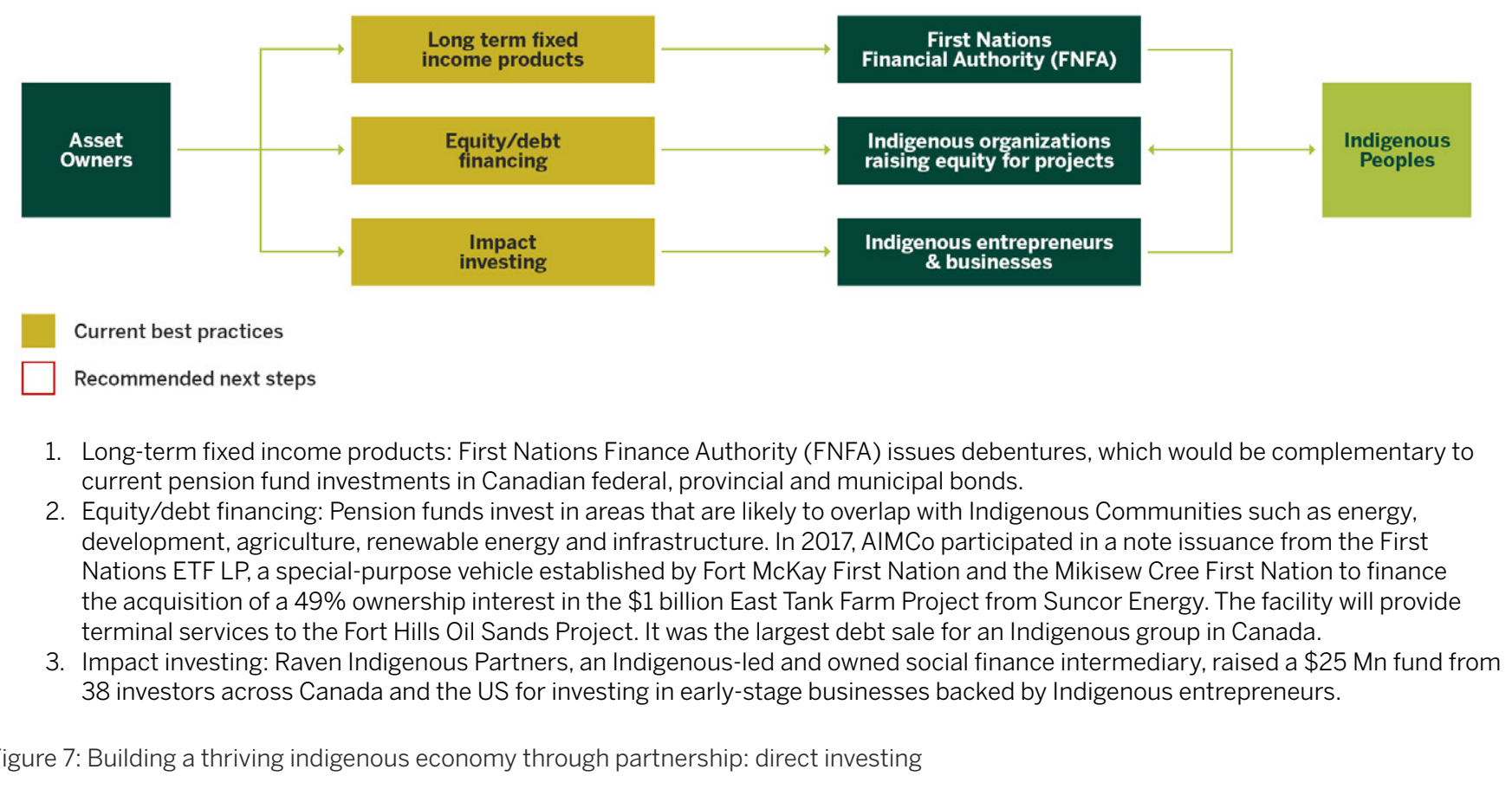




\section{Fiduciary Duty and Indigenous Peoples}

\section{WHAT IS FIDUCIARY DUTY?}

According to Canadian law, a fiduciary duty is an obligation in which one party (the fiduciary) is required to ensure the best interests of another (the beneficiary) when they are in a trust-like relationship. Many discussions have arisen on interpreting the "best interests" of beneficiaries in the past decades, especially in responsible investing (e.g., Bauslaugh, 2021; Principles for Responsible Investment, 2015; Sarra \& Williams, 2018).

\section{FIDUCIARY DUTY, THE CROWN AND INDIGENOUS PEOPLES}

There are two ways in which a fiduciary obligation may arise between the Crown and Indigenous Peoples: 1) When the Crown has discretionary control over a specific or cognizable Indigenous interest, (the "sui generis fiduciary obligation"); 2) Where the Crown has undertaken to exercise its discretionary control over a legal or substantial practical interest in the best interests of a beneficiary (the "ad hoc fiduciary relationship"), here the beneficiaries are Indigenous communities (Morrison, 2018, Online).

Cases of breach of the Crown's breach of fiduciary duty have been brought to courts in the past years (i.e.. Williams Lake Indian Band v. Canada, Coldwater Indian Band v. Canada (Indian and Northern Affairs). The relevance today of a case on the Crown's failure to discharge its fiduciary duty in the 19th century matters to Indigenous communities. As a matter of fact, "the existence and fulfilment of a fiduciary duty might affect how governments deal with project assessments and approvals:

- If a project proponent must seek a governmental decision (such as by way of an assessment or approval in the form of a permit or license) to move forward with the project, that decision often entails the government's exercise of discretionary power under the law:

- If that exercise of a discretionary power under the law will affect a specific Aboriginal right, the governmental actor may be under a fiduciary duty to the relevant Indigenous community: a legal obligation to act in that Indigenous community's best interest - not those of the government, the project proponent, or any other; and,

- If a fiduciary duty exists, the governmental authority must exercise its discretionary control in accordance with the equitable standards that require loyalty, good faith, and full disclosure in relation to that Indigenous community, and in its pursuit of their interests, must exercise the care of a person of ordinary prudence in managing their own affairs. And that duty might very well go far beyond the duty to consult." (Morrison, 2018, Online).
Initially, fiduciary duty was widely interpreted as the obligation of trustees and other fiduciaries to maximize investment returns. Two significant Supreme Court of Canada's decisions - "Peoples Department Stores Inc. (Trustee of) v. Wise" and "BCE v. 1976 Debenture holders" - have contested the well-established definition - inspired from the British Common Law - of best interest as contractual duty bonded to financial interests. These two cases are applied to corporations but can be used in the investment management industry. The Supreme Court of Canada mentioned in the case of BCE v. 1976 Debenture holders that when acting with a view to the best interests of the corporation, one may consider the interests of shareholders, employees, retirees and pensioners, creditors, consumers, and governments; the environment; and the long-term interest of the corporation. The two Supreme Court decisions, Peoples and BCE, were incorporated into the law with a 2019 reform of federal corporate law. Section 1.1. was added to Section 122, which defines the best interest of the corporation.

The best interests of fiduciaries are now understood in broader terms that are not exclusively bound by profits and return on investment. Therefore, this interpretation of fiduciary duties includes considering ESG factors in decision-making. ${ }^{12}$
12 Margaret Hodge, in the U.K. Department of Trade and Industry (DTI) guidance on the duties of company directors, stated: 'There was a time when business success in the interests of shareholders was thought to be in conflict with society's aspirations for people who work in the company or in supply chain companies, for the long-term well-being of the community and protection of the environment. The law is now based on a new approach. Pursuing the interest of shareholders and embracing wider responsibilities are complementary purposes, not contradictory ones: 
FIDUCIARY DUTY AND INDIGENOUS PEOPLES

The modern interpretation of fiduciary duty (Borrow and Praud, 2020: Expert Panel on Sustainable Finance, 2019; Fair Pensions, 2011; Principles for Reponsible Investment et al., 2018; United Nations Environment Programme, 2009) could also be tailored to the needs and values of Indigenous communities. However, these communities are bound by multiple fiduciary duties, making their situation more complex than for other beneficiaries.

First, there are the fiduciary duties of the Crown toward Indigenous Peoples. After the Guerin case. fiduciary duty became central to Section 35 of the Constitution Act, 1982 (Luk, 2013). This section enshrines protections for Indigenous rights. The Crown also owes Indigenous Peoples the duty to consult them. Consultation is a legal obligation that the Crown must fulfill before acting or making decisions that may have consequences for the rights of Indigenous Peoples in Canada.

Second, Indigenous Peoples are also bound by fiduciary duties by their trust. Trustees have severa critical legal duties that dictate how they should invest, manage, and protect assets within a trust, including the best interests of the beneficiaries of the trust. The law is quite clear that negligence can make the trustee personally liable to the trust's beneficiaries.

Third, portfolio managers have the fiduciary duty, linked with their professional obligations and relationships, to look out for the best interests of their clients. In these portfolios, the trustee often hires investment managers, making their contractual agreements to the trustee and not necessarily the trust's beneficiaries. Without clear stipulation of the trustee, the manager applies its fiduciary duties to interpret the best interests and due diligence.

\section{WHY IS THIS TOPIC IMPORTANT?}

Indigenous Peoples have been setting up Indigenous trusts to manage their financial assets to benefit their communities. Trustees of Indigenous trusts are bound by their duty as fiduciaries to act in good faith to the trusts' beneficiaries, which often consist of both current and future generations of community members.
INDIGENOUS TRUSTS

Trusts are increasingly common among Indigenous communities in Canada. Though typically used in family estate planning, trusts can also be very effective for communities looking to set aside and invest assets that will benefit their communities over the long term. Many Indigenous communities received compensation from settlement agreements. They have a responsibility to safeguard the assets for the good of their community and establish a trust to manage their money. The trust can be guided by the Nation's financial management policies or determined by the community. While the trustee is technically in charge of the trust, usually, an investment manager comes into play to guide the trustee through the complex investment chain and offer insights into managing the Nation's wealth.

Then, the investment managers usually assume responsibility for investing activities. They conduct research to guide asset selection, sourcing, and due-diligence activities, with the investment mandate informing the investment allocation. Depending on the team size of the investment management firm or its strategic alignment with responsible investment, the investment manager or the responsible investment team will draft various policies related to shareholder engagement (proxy voting guidelines, shareholder dialogue, shareholder proposals). It is worth mentioning that guidance can also be provided by the trustees; however, the responsibilities are often delegated to investment managers. The investment manager will ensure the ongoing management of portfolios guided by the shareholder engagement documents and, in this case, possibly the trust arrangement linked with commitments to specific environmental or social goals.

These contractual agreements between managers and trustees tend to rely on a more traditional view of fiduciary duties focused on the limits on profits and return on investment. This approach tends to neglect that many Indigenous communities operate through obligations of protection, stewardship, and care towards the land, waters, plants, animals, and their communities.

\section{VISIBILITY OF THIS TOPIC ACROSS THE INVESTMENT CHAIN}

The RRII, led by SHARE and NATOA, has led several initiatives on fiduciary duty in relation to Indigenous Peoples. Through guidance materials, boot camps, educational sessions, and networking events, the RRI has been guiding Indigenous investors to help them define the purpose of their trusts, recognize and uphold fiduciary duty, engage in shareholder engagement activities, and manage their relationships with investment managers to achieve their trusts' objectives. The RRII has also been arranging educational sessions and networking events for individuals in governing roles on the boards of trustees and investment committees of investment managers to help them effectively support Indigenous trusts. 
INDIGENOUS FIDUCIARY DUTY

The argument that Indigenous trusts should be managed according to Indigenous laws was made in a report titled 'Teachings of Sustainability, Stewardship \& Responsibility: Indigenous Perspectives on Obligation, Wealth, Trusts \& Fiduciary Duty,' published by the RRII (Borrows \& Praud, 2020). The reports explain the difference between Indigenous laws and Canadian law concerning fiduciary duty.

The key points discussed in the report include:

- Trusts are crucial fiscal management vehicles for Indigenous Peoples and must be considered unique and viable mechanisms for increasing Indigenous wealth

- Indigenous communities operate through legal obligations of protection, stewardship, and care towards the land, waters, plants, animals, and communities;

- Indigenous decision-makers and trustees with fiduciary obligations must be empowered to apply Indigenous laws; and,

- Concepts of responsible investing, ESG, and intergenerational equity exist in the investment industry. Their expansion to suit Indigenous perspectives can support Indigenous decision-makers in exercising their fiduciary obligations and ultimately benefit the investment industry.

\section{LIMITATIONS OF THE CURRENT TREATMENT OF THIS TOPIC IN THE INVESTMENT CHAIN}

Based on our interviews with investment professionals, very few investment managers and investment advisors currently customize their services to suit the needs of Indigenous trusts. While this is not a breach of their

fiduciary duties as understood in contractual agreements, there has been an opportunistic approach in some cases to engaging with Indigenous Peoples to set up and manage Indigenous trusts without completely taking into consideration their community needs. Moreover, awareness and recognition of Indigenous notions of fiduciary duty are utterly absent in other parts of the investment chain.

\section{RECOMMENDED NEXT STEPS}

To better align asset management practices with the needs of Indigenous Peoples and their trusts, asset managers can:

- Train and build capacity in their organizations on Indigenous rights:

- Consider the impact of company practices on Indigenous Peoples during decision-making.

- Discuss with trustees to have a good understanding of client expectations and expressly stipulate the protection, stewardship, and care towards the land, waters, plants, and animals, as well as their communities directly in the contract between the manager and the trustee;
- Add a stewardship code to/with the trustee. This code would bind all agreements, including with the asset manager: and

- Contribute to capacity-building within the community and see if Indigenous agencies/firms can guide other nations in this process.

\section{RATIONALE FOR NEXT STEPS}

Inclusion of this topic in investment due diligence and ongoing portfolio management activities would help:

- Indigenous investors exercise their rights as investors in corporate Canada; and,

- Indigenous investors leverage the support of non-Indigenous investors to advance Indigenous issues.

\section{FIDUCIARY DUTY AND INDIGENOUS PEOPLES ACROSS THE}

INVESTMENT CHAIN
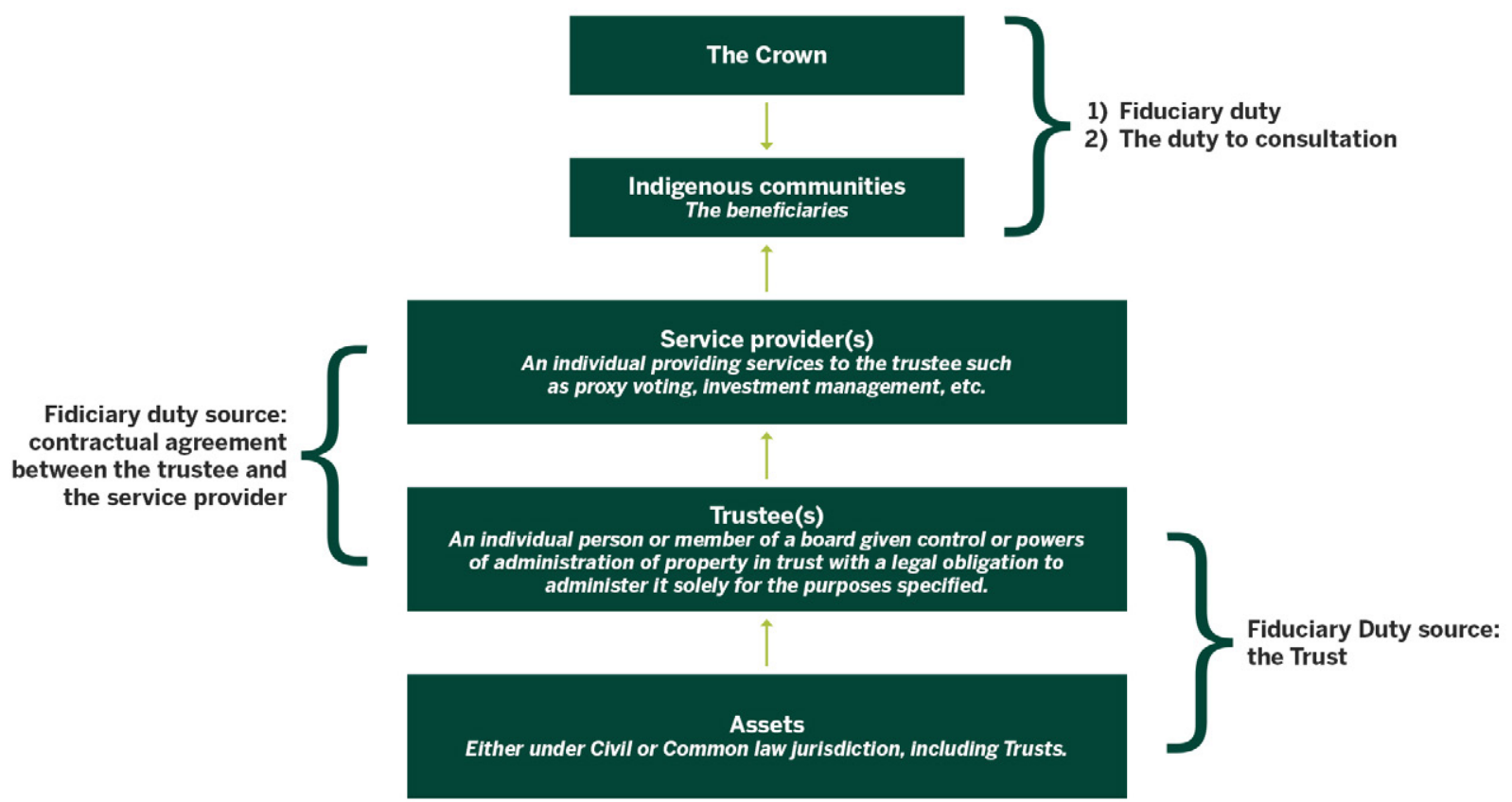

Figure 8: Fiduciary duty and indigenous peoples across the investment chain 


\section{Building an Inclusive and Just}

Transition to a Low-Carbon Economy Through Partnership

\section{WHAT DOES IT MEAN TO BUILD AN INCLUSIVE AND JUST TRANSITION TO A LOW-CARBON ECONOMY THROUGH \\ PARTNERSHIP?}

The Canadian Expert Panel on Sustainable Finance articulated the importance of simultaneous efforts to combat climate change's physical and financial effects while helping the resource-intensive industries in

Canada navigate the intersection between global market access and environmental stewardship (Expert Panel on Sustainable Finance, 2019). With a robust financial sector and capacity for innovation, Canada has the potential to lead the transition towards a low-emission future. The panel recognized 'Inclusive and Just' as one of the guiding principles in these transition efforts.

Indigenous leadership has been actively participating in this transition by advancing ownership positions in clean energy projects across Canada ${ }^{13}$. However, access to capital remains a key impediment. There is potential for investors to step in and partner with the public sector and Indigenous Peoples in capacity development and financing the pathway to an inclusive and just transition in Canada.

\section{WHY IS THIS TOPIC IMPORTANT?}

Canada is warming at double the global average rate, with an average increase in temperature expected to reach 4 degrees in a 2-degrees global warming scenario (Canada's Changing Climate Report, 2019). The costs of climate change and the benefits of the transition to a low-carbon economy will not be distributed equally across Canada's communities, regions, and sectors. The North is expected to warm at double the rate compared to the rest of the country (Expert Panel on Sustainable Finance, 2019). Climate change also particularly affects Indigenous Peoples in the rest of Canada. Since Indigenous communities depend on the land's biodiversity for their social, economic, and cultural well-being, extreme weather events such as floods, wildfires, and heatwaves negatively impact their livelihoods.
Indigenous communities across Canada have benefited from resource revenue-sharing agreements and Impact Benefit Agreements (IBAs) from oil and gas, mining, and forestry projects. Through these arrangements, Indigenous communities can earn steady income over extended periods (Coates, 2015). These funds are deployed for the economic development of communities and help in achieving self-determination. With the ongoing transition to a low-carbon economy, Indigenous communities should benefit from investments in low-carbon infrastructure. To do so, Indigenous organizations should be offered access to capital to acquire equity ownership in low-carbon projects. Moreover, Indigenous-led efforts would also lead to integrating Indigenous knowledge into climate resiliency efforts and contribute to Canada's growth of naturebased climate solutions.

\section{VISIBILITY OF THIS TOPIC IN THE INVESTMENT CHAIN}

Companies in the extractive and renewable energy sectors have been actively partnering with Indigenous communities to develop clean energy projects. However, investors have not yet explored the potential role of direct engagement

To provide access to capital and support new projects in Indigenous communities, the Canada Infrastructure Bank (CIB) launched the Indigenous Community Infrastructure Initiative (ICII) in March 2021 (The Canada Infrastructure Bank (CIB), 2021). The ClB's purpose is to invest $\$ 35$ billion of federal funding in revenuegenerating infrastructure projects in the public interest and attract private capital. The $\mathrm{ClB}$ is a catalyst for private investment in projects that support economic growth for the benefit of Canadians. This initiative will enable new infrastructure projects to increase low-carbon energy supply, reduce greenhouse gas emissions, improve broadband connectivity, etc. However, conversations on the potential to leverage capital from institutional investors are currently missing.

\section{ONEIDA ENERGY STORAGE PROJECT}

The proposed Oneida Energy Storage project, a joint venture between NRStor Incorporated and Six Nations of the Grand River Development Corporation, includes developing a 250 megawatt/1,000 megawatt-hour energy storage facility in Southern Ontario. The facility would draw and store existing surplus baseload and renewable energy during off-peak periods to be released to the Ontario grid when energy demand is at its peak. This project will help Ontario reduce Greenhouse Gas Emissions (GHG) by 4.1 million tonnes, or the equivalent of taking 40,000 cars off the road every year.

The CIB will invest up to $\$ 170$ million in the $\$ 0.5$-billion projects with Oneida Energy Storage LP and private-sector lenders financing the balance of the project's capital cost. This is an excellent example of a partnership between an innovative Canadian cleantech company and a First Nations Community (Canada Infrastructure Bank, 2021; NRSTOR, 2019). 
LIMITATIONS OF THE CURRENT TREATMENT OF THIS TOPIC IN THE INVESTMENT CHAIN

While investors manage financial and reputational risks from the lack of Indigenous consent to projects in the extractive sectors, the opportunities to support Indigenous investment in low-carbon infrastructure have been little explored.

\section{RECOMMENDED NEXT STEPS}

Recommended next steps to enable an inclusive and just transition to a low-carbon economy across the investment chain include:

- Investors including this topic in investment policies for direct investing:

- Investors and asset managers considering opportunities to improve access to capital for Indigenous financial institutions and Indigenous-led initiatives seeking to develop low-carbon projects across

Canada; and,

- Investors encouraging their portfolio companies to partner with Indigenous communities on low-carbon projects through shareholder dialogue.

\section{RATIONALE FOR NEXT STEPS}

Including this topic in investment policy statements and shareholder dialogue would help:

- Generate momentum and lead to collaboration among investors:

- Share best practices and execution support between investors and their portfolio companies:

- Increase funding for nature-based climate solutions in Canada; and

- Build collaboration between Indigenous and non-Indigenous investors on climate change mitigation efforts, facilitating the inclusion of 'l' in the 'E' of ESG.
BUILDING A JUST AND INCLUSIVE TRANSITION TO A LOW-CARBON ECONOMY THROUGH PARTNERSHIP ACROSS THE INVESTMENT CHAIN

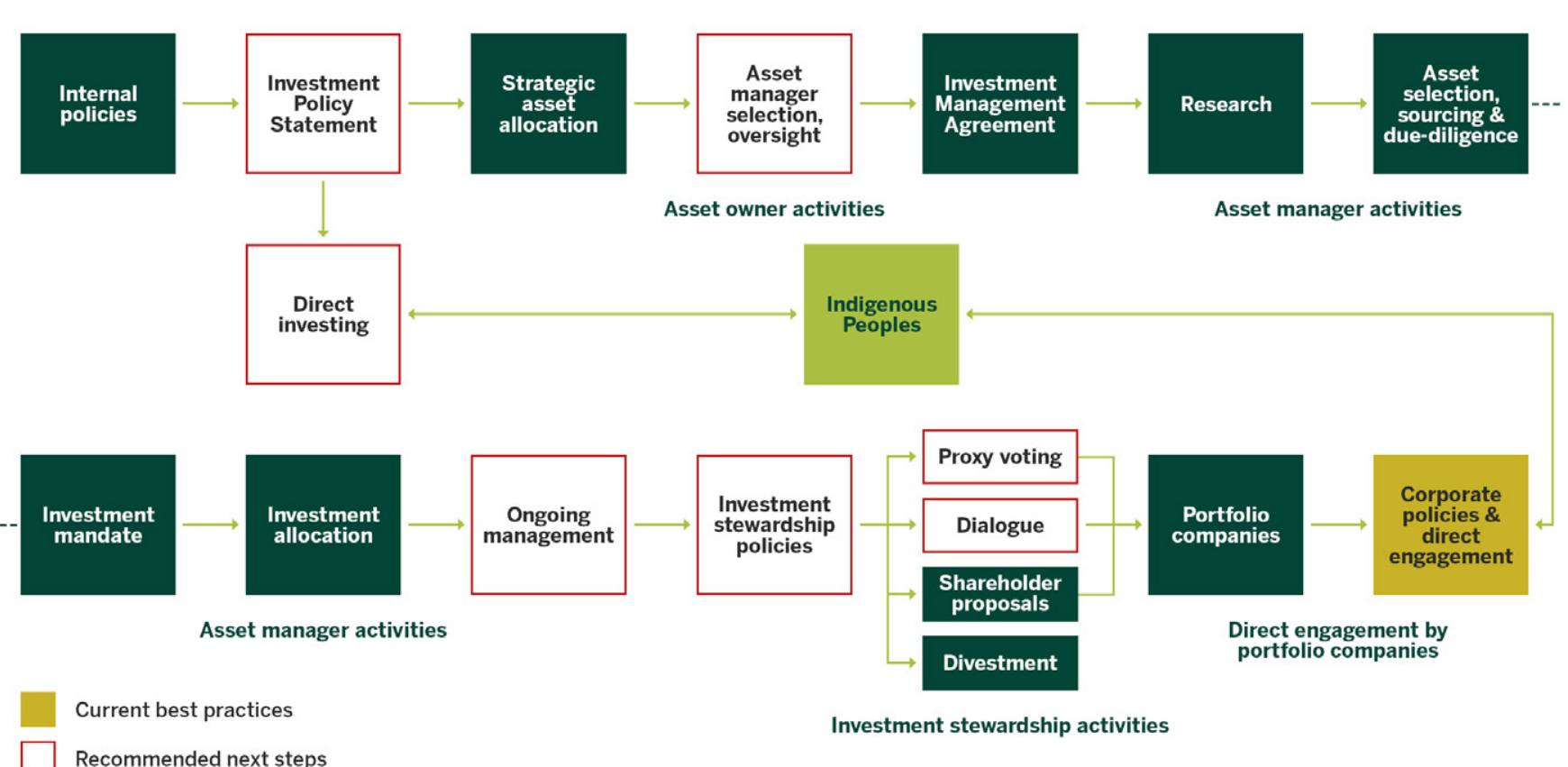

Figure 9: Building a just and inclusive transition to a low-carbon economy through partnership across the investment chain 


\section{Indigenous Environmental Stewardship}

\section{WHAT IS INDIGENOUS ENVIRONMENTAL STEWARDSHIP?}

Indigenous environmental stewardship is a broad term that relates to how Indigenous Peoples interact with the environment to ensure protection, conservation, and sustainability. Indigenous Peoples have always been the stewards of the land, waters, and ecosystem conservation in Canada.

\section{WHY IS THIS TOPIC IMPORTANT?}

Between 1970 and 2016, more than 68 per cent of the mammals, birds, amphibians, reptiles, and fish on Earth disappeared, and more than 85 per cent of wetlands were lost (WWF, 2020). Barnosky et al. (2011) argue that the loss of species is so severe that it could propel the world into a state of mass extinction. If ecosystems die, our societies cannot flourish. Researchers also demonstrated an association between emerging diseases, such as COVID-19, and biodiversity loss (Tollefson, 2020).

Protecting biodiversity also matters to our economies. Ecosystem services, such as crop pollination, water purification, and carbon sequestration, are vital to life and are estimated to be worth between USD \$125 and $\$ 140$ trillion per year, more than one-and-a-half times the global GDP (OECD 2019). The current biodiversity loss puts our societies and economies in significant danger (Chandellier \& Malacain, 2021).

Indigenous communities, representing only five per cent of the global population, are the stewards of 80 per cent of the planet's biodiversity (Raygordetsky, 2018). Indigenous Peoples have unique perspectives and knowledge, which can help improve conservation. Therefore, collaborating with Indigenous Peoples is crucial to conserving biodiversity.

\section{VISIBILITY OF THIS TOPIC IN THE INVESTMENT CHAIN}

Canada outlined clear environmental priorities in its 2021-2025 federal budget and committed to conserving 25 per cent of its lands and oceans by 2025. In 2018, Canada's federal government earmarked CAD $\$ 1.3$ billion over the next five years to expand protected areas and help endangered and threatened species. However, the government also estimated that the country needed an additional CAD $\$ 500$ billion to be climate-resilient, calling private investors to step $\mathrm{in}^{14}$.

Historically funded by governments and non-profit organizations, the traditional biodiversity funding models lag the scale of capital required to effectively respond to the biodiversity crisis, citing the need for innovative financial instruments.

Indigenous-led conservation finance, which includes Indigenous environmental stewardship when raising and managing capital to support land, water, and resource conservation, is an emerging field that could address the biodiversity crisis.

\section{AN INDIGENOUS-LED CONSERVATION FINANCE INSTRUMENT}

\section{THE DESHKAN ZIIBI CONSERVATION IMPACT BOND}

The Carolinian Zone (stretching across Toronto and Windsor in Southwestern Ontario, Canada) is one of the most biodiverse regions in Canada and is home to one-third of species at risk in the country. It is the most threatened ecosystem due to the high population density in the region. Studies have shown that natural infrastructure, which incorporates traditional knowledge, including that of Indigenous Peoples, can help in the conservation of such threatened areas. An advantage of a nature-based solution is that it grows in value over time, demonstrating cost savings for agriculture and other land uses.

The Deshkan Ziibi Conservation Impact Bond (CIB) was developed as an innovative place-based financial product to fund the natural conservation efforts in the Carolinian zone. It uses an outcomes-based payfor-performance model with private investors being paid out by outcome partners to set performance targets. This financial instrument brought together First Nations and other communities to jointly care for the land and was designed through extensive consultations with finance experts and other stakeholders. Carolinian Canada, a coalition of leaders sustaining healthy landscapes in the zone, plans to raise $\$ 2$ million by 2023 to meet its target of restoring 1,000 acres of land (SVX, 2020).

Companies in the extractive sector demonstrate engagement with Indigenous communities on environmenta stewardship, but the implementation of nature-based solutions informed by Indigenous knowledge remains limited 15

14 Studies have shown that to meet international biodiversity targets and effectively respond to the biodiversity crisis will require USD \$722-967 billion annually by 2030 (Deutz et al., 2020).

15 Examples include Mercer International (Mercer Peace River's Forest Management project). Teck Resources (Kitaskino Nuwenëne Wildland Provincial Park) 
LIMITATIONS OF THE CURRENT TREATMENT OF THIS TOPIC IN THE INVESTMENT CHAIN

The potential for investments in Indigenous-led nature-based solutions has only begun to be explored. Including Indigenous knowledge in conservation decisions is essential to achieve conservation outcomes (Artelle et al., 2019). Yet Indigenous environmental knowledge is rarely mentioned in the investment chain.

Conservation finance urgently needs more capital to support green infrastructure in the country. Creating novel Indigenous-led conservation products is a necessary step towards this endeavour

\section{RECOMMENDED NEXT STEPS}

Recommended next steps to support Indigenous environmental leadership across the investment chain include:

- Investors exploring the potential for direct investment in Indigenous-led nature-based solutions;

- Investors employing shareholder dialogue to encourage portfolio companies to engage with Indigenous communities on environmental stewardship: and,

- Investors and their stakeholders supporting the development of Indigenous-led conservation finance products.

\section{RATIONALE FOR NEXT STEPS}

Including this topic in investments and ongoing portfolio management activities would help:

- Indigenous communities and non-Indigenous investors collaborate on protecting the environment. facilitating Indigenous environmental stewardship in ESG criteria;

- Achieve the objective of the Canadian government of conserving 25 per cent of lands and oceans by 2025 and 30 per cent by 2030 - whose efforts will have to be based on science, Indigenous knowledge, and local perspectives:

- Contribute to the Truth and Reconciliation process by including Indigenous knowledge in investment decision-making; and,

- Build green infrastructure to support a climate-resilient and inclusive economy.
INDIGENOUS ENVIRONMENTAL STEWARDSHIP ACROSS THE INVESTMENT CHAIN
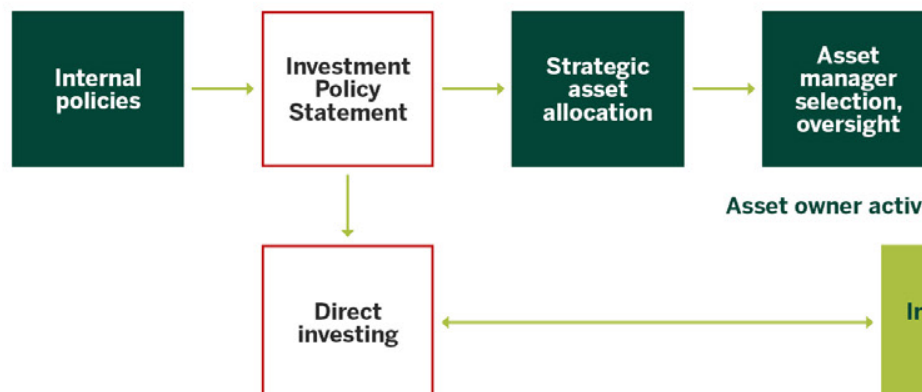

Asset owner activities

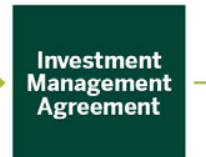
Penous

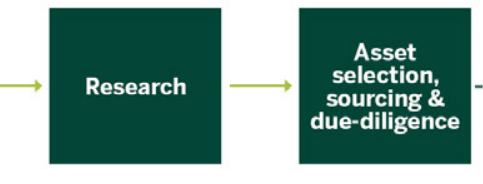

Asset manager activities
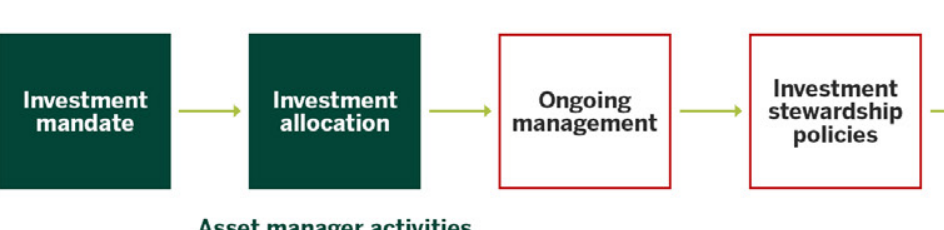

Asset manager activities
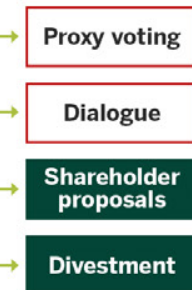

Investment stewardship activitios

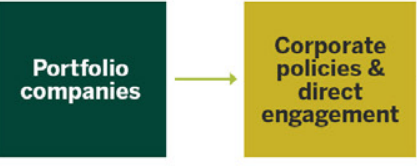

Direct engagement by
portfolio companies

$\square$ Recommended

Figure 10: Indigenous environmental stewardship across the investment chain 


\section{List of Abbreviations}

\begin{tabular}{|l|l|l|l|}
\hline AFIs & Aboriginal Financial Institutions & GRI & Global Reporting Initiative \\
\hline BIPOC & $\begin{array}{l}\text { Black and Indigenous Communities and } \\
\text { People of Colour }\end{array}$ & NACCA & $\begin{array}{l}\text { National Aboriginal Capital Corporations } \\
\text { Association }\end{array}$ \\
\hline BLM & Black Lives Matter & RIA & Responsible Investment Association \\
\hline CBCA & Canada Business Corporations Act & RRII & $\begin{array}{l}\text { Reconciliation and Responsible } \\
\text { Investment Initiative }\end{array}$ \\
\hline CCAB & Canadian Council for Aboriginal Business & SASB & $\begin{array}{l}\text { Sustainability Accounting Standards } \\
\text { Board }\end{array}$ \\
\hline CDSB & Climate Disclosure Standards Board & SHARE & $\begin{array}{l}\text { Shareholder Association for Research and } \\
\text { Education }\end{array}$ \\
\hline CIB & Canadian Infrastructure Bank & TCFD & $\begin{array}{l}\text { Task Force on Climate-related Financial } \\
\text { Disclosures }\end{array}$ \\
\hline UN PRI & United Nations Principles for Responsible & UN & United Nations \\
\hline ESG & Environmental Social Governance & UNDRIP & $\begin{array}{l}\text { United Nations Declaration on the Rights } \\
\text { of Indigenous People }\end{array}$ \\
\hline FPIC & Free, prior and informed consent & UN PRI & $\begin{array}{l}\text { United Nations Principles for Responsible } \\
\text { Investment }\end{array}$ \\
\hline
\end{tabular}

\section{List of References}

Aguanno, M., \& Arjaliès, D.-L. (2020). What does it mean to engage in a process of decolonization? Unpublished Working Paper.

Cision. (2020, November 25). CEOs of eight leading Canadian pension plan investment managers call on companies and investors to help drive sustainable and inclusive economic growth. https://www.newswire.ca/ news-releases/ceos-of-eight-leading-canadian-pension-plan-investment-managers-call-on-companiesand-investors-to-help-drive-sustainable-and-inclusive-economic-growth-844608554.html

Arjaliès, D.-L., Grant, P., Hardie, I., MacKenzie, D., \& Svetlova, E. (2017). Chains of Finance: How Investment Management is Shaped. Oxford University Press.

Artelle, K. A., Zurba, M., Bhattacharyya, J., Chan, D. E., Brown, K., Housty, J., \& Moola, F. (2019). Supporting resurgent Indigenous-led governance: A nascent mechanism for just and effective conservation. Biological Conservation, 240, 108284

Barnosky. A. D., Matzke, N., Tomiya, S., Wogan, G. O., Swartz, B., Quental, T. B., Marshall, C., McGuire, J. L. Lindsey, E. L. \& Maguire, K. C. (2011). Has the Earth's sixth mass extinction already arrived? Nature, 471(7336),

Bauslaugh, R. (2021). Climate Change: Legal Implications for Canadian Pension Plan Fiduciaries and PolicyMakers (p. 25). McCarthy Tétrault LLP. https://ccli.ubc.ca/wp-content/uploads/2021/05/BauslaughPension-Opinion-1.pdf

Borrows, J., \& Praud, S. (2020). Teachings of Sustainability, Stewardship \& Responsibility: Indigenous Perspectives on Obligation, Wealth, Trusts \& Fiduciary Duty (p. 48). SHARE.

https://reconciliationandinvestment.ca/2020/09/25/launch-of-discussion-paper-teachings-ofsustainability-stewardship-responsibility

British Columbia Investment Management Corporation (BCI). (2019). ESG Annual Report. https://www.bci.ca/ wp-content/uploads/2020/06/2019-ESG-Annual-Report.pdf

Brunette, C., \& Richmond, C. (2019). Guide for working with Indigenous students - Interdisciplinary development initiative (IDI) in applied Indigenous scholarship. Western University.

Cameco. (2021). Our Approach to ESG Reporting: Social. https://www.cameco.com/about/sustainability/ourapproach-to-esg-reporting/social

Groupe d'experts sur la finance durable \& Environnement et changement climatique Canada. (2019). Rappor final du Groupe d'experts sur la finance durable: Mobiliser la finance pour une croissance durable. http://epe. lac-bac.gc.ca/100/201/301/weekly_acquisitions_list-ef/2019/19-24/publications.gc.ca/collections/ collection 2019/eccc/En4-350-2-2019-fra.pdf 
Canada Infrastructure Bank. (2021). Canada Infrastructure Bank to invest up to $\$ 170$ million in one of the world's largest clean energy storage projects. Cision. https://www.newswire.ca/news-releases/canadainfrastructure-bank-to-invest-up-to-170-million-in-one-of-the-world-s-largest-clean-energy-storageprojects-873859179.htm

Chandellier, J., \& Malacain, M. (2021). Biodiversity and Re/insurance: An Ecosystem at Risk. Muséum Nationale d'Histoire Naturelle.

CISION. (2020). https:///www.newswire.ca/news-releases/ceos-of-eight-leading-canadian-pensionplan-investment-managers-call-on-companies-and-investors-to-help-drive-sustainable-and-inclusiveeconomic-growth-844608554.htm

Cho, C. (2020, December 31). My Comment Letter to the IFRS Foundation about the Consultation Paper on Sustainability Reporting. Accounting Resources Centre- European Accounting Association.

https://arc.eaa-online.org/blog/my-comment-letter-ifrs-foundation-about-consultation-papersustainability-reporting

Coates, K. S. (2015). Sharing the Wealth - How resource revenue agreements can honour treaties, improve communities, and facilitate Canadian development. A Macdonald-Laurier Institute Publication.

Collins, P. H. (2000). Black feminist thought: Knowledge, consciousness, and the politics of empowerment. Routledge.

Department of Justice. (2017, July 14). Principles respecting the Government of Canada's relationship with Indigenous Peoples. Government of Canada.

https://www.justice.gc.ca/eng/csj-sjc/principles-principes.html

Deutz, A., Heal, G. M., Niu, R., Swanson, E., Townshend, T., Zhu, L., Delmar, A., Meghii, A., Sethi, S. A., \& Tobin-de la Puente, J. (2020). Financing Nature: Closing the Global Biodiversity Financing Gap. The Paulson Institute, The Nature Conservancy, and the Cornell Atkinson Center for Sustainability) https://www.paulsoninstitute.org/wpcontent/uploads/2020/10/FINANCING-NATURE Full-Report_Final-with-endorsements 101420.pdf

Eccles, R. G., Krzus, M. P., Rogers, J., \& Serafeim, G. (2012). The Need for Sector-Specific Materiality and Sustainability Reporting Standards. Journal of Applied Corporate Finance, 24(2), 65-71.

https://doi.org/10.1111/i.1745-6622.2012.00380x

Expert Panel on Sustainable Finance. (2019). Mobilizing Finance for Sustainable Growth-Final Report of the Expert Panel on Sustainable Finance (p. 65). Government of Canada. http://publications.gc.ca/collections/ collection 2019/eccc/En4-350-2-2019-eng.pdf

Fair Pensions. (2011). Protecting Our Best Interests: Rediscovering Fiduciary Obligation (p. 140). Fairshare Educational Foundation

Gompers, P., \& Kovvali, S. (2018). The Other Diversity Dividend. Harvard Business Review. https://hbr.org/2018/07/the-other-diversity-dividend

Government of Canada. (2019). Canada's Changing Climate Report. https://www.nrcan.gc.ca/sites/www. nrcan.gc.ca/files/energy/Climate-change/pdf/CCCR_FULLREPORT-EN-FINAL.pdf
Guillot, J. \& Hales, J. (2021, May 13). Materiality: The Word that Launched a Thousand Debates. SASB Blog. https://www.sasb.org/blog/materiality-the-word-that-launched-a-thousand-debates

Gulati, S. \& Burleton, D. (2011). Estimating the size of the aboriginal market in Canada. TD Special Report.

Indigenous Works. (2017). Researching Indigenous Partnerships: An Assessment of Corporate-Indigenous Relations, Summary Report 2017. Indigenous Works.

Luk, S. (2013). Not So Many Hats: The Crown's Fiduciary Obligations to Aboriginal Communities since Guerin Saskatchewan Law Review, 76(1), 33.

Mueller, R. O., \& Ising, E. (2017). Shareholder Proposal Developments During the 2017 Proxy Season. Harvard Law School Forum on Corporate Governance and Financial Regulation.

Nabylah Abo, D., Coin, I., \& Filippo, M. D. (2020, June 25). Investors must act now to tackle deforestation and threats to indigenous people in the Amazon. PRI. https://www.unpri.org/pri-blog/investors-must-act-now-totackle-deforestation-and-threats-to-indigenous-people-in-the-amazon/5985.article

NEl Investments. (2021). Focus List 2021: A guide to our ESG themes and the companies we're talking to this year (p. 19). NEl Investments. https://www.neiinvestments.com/documents/FocusList/NEI FocusList 2021 EN.pdf

NRSTOR. (2019). Canada Infrastructure Bank Signs Memorandum of Understanding for Oneida Energy Storage Project. http://nrstor.com/2021/01/12/canada-infrastructure-bank-signs-memorandum-ofunderstanding-for-oneida-energy-storage-project

Organisation for Economic Co-operation and Development (OECD). (2018). Inclusive Growth. https://www.oecd.org/inclusive-growth/\#introduction

Orowitz, H., \& Rosati, B. (2021, June 21). An Early Look at the 2020 Proxy Season. An Early Look at the 2020 Proxy Season. https://corpgov.law.harvard.edu

Osipovich, A., \& Otani, A. (2020, December 1). Nasdaq Seeks Board-Diversity Rule That Most Listed Firms Don't Meet. The Wall Street Journal, Online.

Podlasly, M., Lindley-Peart, M., \& von der Porten, S. (2021). Indigenous Sustainable Investment: Discussing Opportunities in ESG. The First Nations Major Projects Coalition. https://www.fnmpcindustryevent.com/esg. primer

PRI. (2018, July 19). Human rights and the extractives sector. PRI https://www.unpriorg/social-issues/ human-rights-and-the-extractives-sector/3426.article

PRI. (2020). Annual Report 2020 (p. Online). https://www.unpri.org/about-the-pri/annualreport-2020/6811.article

Principles for Responsible Investment, United Nations Environment Programme, Generation Foundation, \& Finance for Tomorrow. (2018). La responsabilité fiduciaire au 21e siècle: La feuille de route de la finance durable pour la France (p. 24) 
Principles for Responsible Investment. (2015). Fiduciary Duty in the 21st Century.

Raufflet, E Baba, S. Perras, C. \& Delannon, N. (2013). Social License In S. O. Idowu, N. Capaldi, L. Zu, \& A. D. Gupta (Eds.), Encyclopedia of Corporate Social Responsibility (pp. 2223-2230). Springer Berlin Heidelberg. https://doi.org/10.1007/978-3-642-28036-8 77

Raygordetsky, G. (2018). Indigenous Peoples defend Earth's biodiversity - But they're in danger. Nationa Geographic, Online. https://www.nationalgeographic.com/environment/article/can-indigenous-landstewardship-protect-biodiversity-

Reconciliation Canada. (2021). Economic Reconciliation. Reconciliation Canada. https://reconciliationcanada. ca/programs-initiatives/economic-reconciliation

Reynolds, F. (2020, June 5). Responsible investors must unite for racial justice. Corporate Knights.

https://www.corporateknights.com/responsible-investing/responsible-investors-must-unite-racial-justice

RIA. (2020, November 26). Canadian ESG Assets Surge to \$3.2 Trillion. Responsible Investment Association. https://www.riacanada.ca/news/canadian-esg-assets-surge-to-3-trillion

RIA. (2021). What is Responsible Investment? Responsible Investment. https://www.riacanada.ca/ responsible-investment

Rosenblum, D. (2020, November 5). California Pioneers New Quotas For People Of Color \& LGBT People. Forbes, Online.

RRII. (2020, March 20). Proxy Alert: Indigenous Rights at the Bank of Nova Scotia. Reconciliation and Responsible Investment Initiative. https://reconciliationandinvestment.ca/2020/03/20/bns-proxy-alert

Sarra, J., \& Williams, C. (2018). Legal research papers on Canadian fiduciary duties and disclosure obligations in the climate change context. Commonwealth Climate and Law Initiative. https://ccli.ouce.ox.ac.uk/ publications

SHARE. (2017, April 12). Proxy Alert: Enbridge Inc. - Shareholder proposal on environmental and Indigenous rights due diligence [SHARE]. https://share.ca/proxy-alert-enbridge-inc-shareholder-proposal-onenvironmental-and-indigenous-rights-due-diligence

SHARE. (2018a, March 5). Human rights due diligence. SHARE. https://share.ca/share-proposals/humanrights-due-diligence

SHARE. (2018b, April 11). Board diversity. SHARE. https://share.ca/share-proposals/board-diversity

SHARE. (2019, April 1). Proxy Alert: Shareholder proposal on Indigenous rights practices at TransCanada Corporation. SHARE Website https://share.ca/proxy-alert-2019-transcanada-indigenous

SHARE. (2020, April 7). Indigenous Rights at the Bank of Nova Scotia. SHARE https://share.ca/shareproposals/indigenous-rights-at-the-bank-of-nova-scotia

SHARE. (2021, May 12). Press Release: TMX Group Limited shareholders vote in favour of company-supported shareholder proposal on Indigenous inclusion - SHARE SHARE Website. https://share ca/press-release-tmx-vote-reconcilation

Slater, S. J., Christiana, R. W. \& Gustat, J. (2020). Peer Reviewed: Recommendations for keeping parks and green space accessible for mental and physical health during COVID-19 and other pandemics. Preventing Chronic Disease, 17.

Statistics Canada. (2020, May 26). Indigenous people in urban areas: Vulnerabilities to the socioeconomic impacts of COVID-19. Government of Canada. https://www150.statcan.gc.ca/n1/pub/45-28-

\section{1/2020001/article/00023-eng.htm}

SVX. (2020). Financing Conservation in the Carolinian Zone, Part 1: The Deshkan Ziibi Conservation Impact Bond. https://thesvx.medium.com/carolinian-canada-conservation-impact-bond-introduction-part-i$83 \mathrm{e} 80 \mathrm{~cd} 247 \mathrm{fa}$

Teck. (2021). Indigenous Peoples Policy (p. 1). Teck. https://www.teck.com/responsibility/approach-toresponsibility/policies-and-commitments/policies/indigenous-peoples-policy

Telus. (2021, March 2). Indigenous entrepreneurs receive \$25 million boost from world's first Indigenous Impact Fund. https://www.telus.com/en/pollinatorfund/blog/raven-indigenous-capital-partners-impact-fund

The Canada Infrastructure Bank (CIB). (2021). The Canada Infrastructure Bank launches its Indigenous Community Infrastructure Initiative to accelerate new investment and reduce the infrastructure gap. https:// www.newswire.ca/news-releases/the-canada-infrastructure-bank-launches-its-indigenous-communityinfrastructure-initiative-to-accelerate-new-investment-and-reduce-the-infrastructure-gap-848675661. htm

Thorpe-Moscon, J. \& Ohm, J. (2021). Building inclusion for Indigenous Peoples in Canadian workplaces (p. 11). Catalyst. https://www.catalyst.org/wp-content/uploads/2020/12/IndigenousPeoplesCanadaReport English final.pdf

Tollefson, J. (2020). Why deforestation and extinctions make pandemics more likely. Nature, 584(7820) $175-176$.

Trichur, R. (2021, May 7). Opinion: TMX backing of shareholder proposal on Indigenous inclusion will ripple through capital markets. Globe and Mail, Online.

Truth and Reconciliation Commission of Canada. (2015). Honouring the truth, reconciling for the future: Summary of the final report of the Truth and Reconciliation Commission of Canada.

http://epe.lac-bac.gc.ca/100/201/301/weekly_acquisition_lists/2015/w15-24-F-E.html/collections/ collection 2015/trc/IR4-7-2015-eng.pdf

United Nations. (2007). United Nations Declaration on the Rights of Indigenous Peoples. https://www.un.org/ development/desa/indigenouspeoples/wp-content/uploads/sites/19/2018/11/UNDRIP_E web.pd

United Nations Environment Programme. (2009). Fiduciary responsibility: Legal and practical aspects of 
integrating environmental, social and governance issues into institutional investment (p. 92). A report by the Asset Management Working Group of the United Nations Environment Programme Finance Initiative.

Wheatley, K. (2021). All Hands on Deck: Opportunities for investment management firms to advance reconciliation (p. 17). RRII.

https://reconciliationandinvestment.ca/2021/07/08/all-hands-ondeck

Wheatley, K., \& Lau, J. (2021). Business and Reconciliation: An update Exploring Performance of Public Companies in Canada ( $p$

35). RRII. https://reconciliationandinvestment.ca/wp-content/ uploads/2021/03/SHARE-RRII-Business-and-Reconciliation Final-1. pdf

World Economic Forum. (2014). 1.3 The investment value chain (Direct Investing by Institutional Investors: Implications for Investors and PolicyMakers, p. 38). World Economic Forum. http://www3.weforum.org/ docs/WEFUSA DirectInvestingInstitutionallnvestors.pdf

WWF. (2020). Living Planet Report 2020-Bending the Curve of Biodiversity Loss (R. E. A. Almond, M. Grooten, \& T. Petersen, Eds.). WWF. Yuval-Davies, N. (2006). Intersectionality and feminist politics. European Journal of Women's Studies, 13(3), 193-209. 